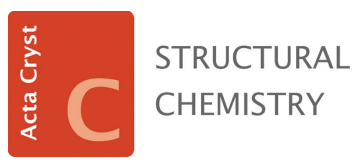

ISSN 2053-2296

\section{Coordination chemistry of polynitriles. Part 9. Decacyanoferrocene revisited. Crystal and molecular structure of cis- $\left[\left\{\mathrm{C}_{5}(\mathrm{CN})_{5}\right]_{2}(\mathrm{MeCN})_{4} \mathrm{Fe}\right]$}

\author{
Karlheinz Sünkel* and Tobias Blockhaus
}

Ludwig-Maximilians-Universität München, Department Chemie, Butenandtstrasse 9, 81377 Munich, Germany. *Correspondence e-mail: suenk@cup.uni-muenchen.de

Received 1 September 2021

Accepted 11 January 2022

Edited by E. Reinheimer, Rigaku Americas Corporation, USA

Keywords: ferrocene; pentacyanocyclopentadienide; $\pi-\pi$ interactions; weak interactions; decacyanoferrocene; crystal structure.

CCDC reference: 2141277

Supporting information: this article has supporting information at journals.iucr.org/c

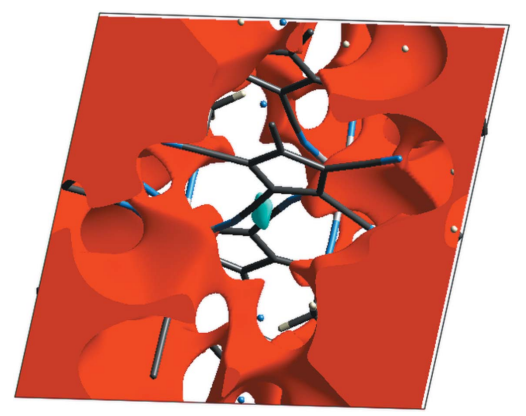

(c) () OPEN O ACCESS
The reaction of $\mathrm{Ag}\left[\mathrm{C}_{5}(\mathrm{CN})_{5}\right]$ with anhydrous $\mathrm{FeCl}_{2}$ in acetonitrile leads to colourless crystals of tetrakis(acetonitrile- $\kappa N$ ) bis(pentacyanocyclopentadienido$\kappa N)$ iron(II) acetonitrile 1.8-solvate, $\left[\mathrm{Fe}\left(\mathrm{C}_{10} \mathrm{~N}_{5}\right)_{2}\left(\mathrm{CH}_{3} \mathrm{CN}\right)_{4}\right] \cdot 1.8 \mathrm{CH}_{3} \mathrm{CN}$ or cis$\left[\left\{\mathrm{C}_{5}(\mathrm{CN})_{5}\right\}_{2}(\mathrm{MeCN})_{4} \mathrm{Fe}\right] \cdot 1.8 \mathrm{MeCN}$. The compound crystallizes in the triclinic space group $P \overline{1}$ as monomers, which exhibit weak $\mathrm{C}-\mathrm{H} \cdots \mathrm{N}$ and $\pi-\pi$ interactions. The crystals contain $c a 20 \%$ solvent-accessible voids, which are nearly completely filled by two $\mathrm{MeCN}$ molecules.

\section{Introduction}

The term 'decacyanoferrocene' appeared first in a publication about 'diazotetracyanocyclopentadiene' (Webster, 1966) and later in two US patents by the same author (Webster, 1970, 1974). It was used for the reaction product from silver pentacyanocyclopentadienide and $\mathrm{FeCl}_{2}$ in acetonitrile, which led to 'light-green crystals of decacyanoferrocene', which were characterized, after drying at $112{ }^{\circ} \mathrm{C}$ under vacuum, by elemental analysis and IR and UV spectroscopy as ' $\mathrm{C}_{20} \mathrm{~N}_{10} \mathrm{Fe} \cdot x \mathrm{H}_{2} \mathrm{O}$ '. No indication or proof was given for the formulation as a 'ferrocene'. A couple of years later, a different research group repeated the experiment and described the primary product as 'white crystals' (Christopher \& Venanzi, 1973). Drying of the crystals at room temperature in vacuo produced a white solid that still, according to its IR spectrum, contained acetonitrile. Further drying at $110^{\circ} \mathrm{C}$ in vacuo produced a pale-yellow-green product, which analyzed as ' $\mathrm{C}_{20} \mathrm{~N}_{10} \mathrm{Fe} \cdot x \mathrm{H}_{2} \mathrm{O}$ ' and was further characterized by IR spectroscopy and magnetic and conductivity measurements. In the absence of a crystal structure determination, these authors postulated a 'polymeric structure in which the iron is in an approximately octahedral environment', in which 'each PP group bridges three iron atoms'. Within the last 15 years, the coordination chemistry of the pentacyanocyclopentadienide anion has been studied intensively by us and others (Sünkel \& Reimann, 2013; Sünkel \& Nimax, 2018; Nimax et al., 2018; Blockhaus \& Sünkel, 2021; Bacsa et al., 2011; Less et al., 2013). These studies showed that $\left[\mathrm{C}_{5}(\mathrm{CN})_{5}\right]^{-}$could behave either as a noncoordinating anion or use one to its five cyano groups for coordination, sometimes even in a bridging $\mu_{2}-\kappa^{1}: \kappa^{1}$ fashion. We had also treated $\mathrm{FeCl}_{2}$ with $\mathrm{Ag}\left[\mathrm{C}_{5}(\mathrm{CN})_{5}\right]$ in methanol. Recrystallization from $\mathrm{MeOH}$ gave crystals of trans$\left[\left\{\mathrm{C}_{5}(\mathrm{CN})_{5}\right\}_{2} \mathrm{Fe}\left(\mathrm{H}_{2} \mathrm{O}\right)_{4}\right]$, in which both anions used only one cyano function each for coordination to iron in a mononuclear compound (Sünkel et al., 2019). Individual molecules were connected via hydrogen bridges into a three-dimensional 
Table 1

Experimental details.

\section{Crystal data}

Molecular formula

Chemical formula

$M_{\mathrm{r}}$

Crystal system, space group

Temperature (K)

$a, b, c(\AA)$

$\alpha, \beta, \gamma\left({ }^{\circ}\right)$

$V\left(\AA^{3}\right)$

$Z$

Radiation type

$\mu\left(\mathrm{mm}^{-1}\right)$

Crystal size (mm)

Data collection

Diffractometer

Absorption correction

$T_{\min }, T_{\max }$

No. of measured, independent and observed

$[I>2 \sigma(I)]$ reflections

$R_{\text {int }}$

$(\sin \theta / \lambda)_{\max }\left(\AA^{-1}\right)$

Refinement

$R\left[F^{2}>2 \sigma\left(F^{2}\right)\right], w R\left(F^{2}\right), S$

No. of reflections

No. of parameters

No. of restraints

$\mathrm{H}$-atom treatment

$\Delta \rho_{\max }, \Delta \rho_{\min }\left(\mathrm{e} \AA^{-3}\right)$
$\left[\mathrm{Fe}\left(\mathrm{C}_{10} \mathrm{~N}_{5}\right)_{2}\left(\mathrm{C}_{2} \mathrm{H}_{3} \mathrm{~N}\right)_{4}\right] \cdot 1.8 \mathrm{C}_{2} \mathrm{H}_{3} \mathrm{~N}$

$\mathrm{C}_{31.6} \mathrm{H}_{17.4} \mathrm{FeN}_{15.8}$

674.29

Triclinic, $P \overline{1}$

109

11.9972 (7), 12.8711 (7), 13.0907 (8)

$62.528(2), 82.929(2), 77.210$ (2)

1748.47 (18)

2

Mo $K \alpha$

0.48

$0.05 \times 0.04 \times 0.03$

Bruker D8 Venture

Multi-scan (SADABS; Krause et al., 2015)

$0.616,0.745$

$17051,7081,5145$

0.042

0.626

$0.064,0.163,1.03$

7081

464

3

$\mathrm{H}$-atom parameters constrained

$0.81,-0.63$
0.47

17056, 7083, 5145

$\mathrm{C}_{28} \mathrm{H}_{12} \mathrm{FeN}_{14}$ 600.37

$0.061,0.141,1.04$

7083

392

0

$0.77,-0.64$

Computer programs: APEX2 (Bruker, 2011), SAINT (Bruker, 2011), SHELXT2014 (Sheldrick, 2015a), SHELXL2018 (Sheldrick, $2015 b$ ) and Mercury (Macrae et al., 2020).

network. Since all the above-mentioned reports described the formation of (either 'light green' or 'white') crystals as the primary product of the reaction in acetonitrile, we decided to repeat this reaction and to study the crystals.

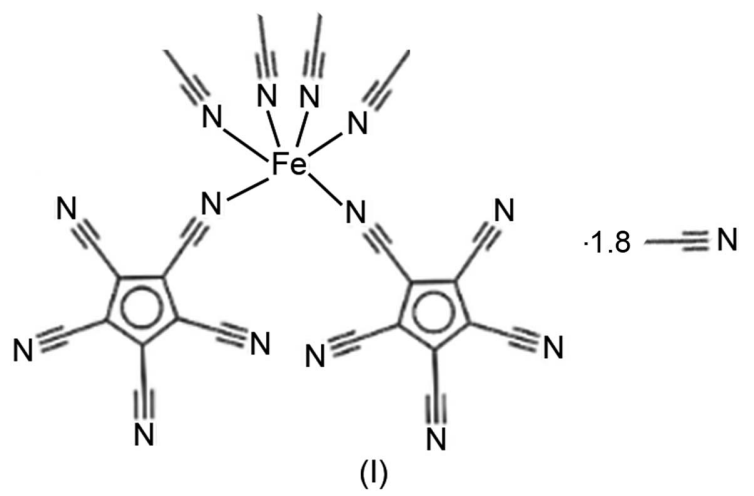

Scheme 1

\section{Experimental}

\subsection{Synthesis and crystallization}

The title compound, tetrakis(acetonitrile- $\kappa N$ )bis(pentacyanocyclopentadienido- $\kappa N$ )iron(II) acetonitrile disolvate, (I) (Scheme 1), was prepared as described in the literature (Webster, 1966; Christopher \& Venanzi, 1973). Recrystallization of the crude product by slow evaporation of an acetonitrile solution under an argon atmosphere gave colourless crystals suitable for X-ray diffraction analysis. Heating the crystals at $110^{\circ} \mathrm{C}$ in vacuo for several hours left an amorphous powder. All attempts to obtain crystals of this product by dissolution in a noncoordinating solvent met with failure.

\subsection{Refinement}

The structure refinement showed, besides the molecular unit, two lattice acetonitrile $(\mathrm{MeCN})$ molecules, which were both disordered. The disorder of one $\mathrm{MeCN}$ molecule could be resolved with the help of restraints into two positions in relative 80:20 occupancies. The disorder of the second molecule, however, could not be resolved. Due to some unfavourable close contacts with the 'minor' molecule, the siteoccupancy factor (s.o.f.) of the second molecule was reduced to 0.8 anyway. After inclusion of these $\mathrm{MeCN}$ molecules, PLATON (Spek, 2020) analysis showed no more solventaccessible voids. The results of the refinement using this model are shown in the second column of Table 1. As the PLATON analysis of the structure without the lattice acetonitrile molecules showed $20 \%$ solvent-accessible voids (for a 'cavity plot', see Fig. S1 of the supporting information), a refinement using the SQUEEZE routine (Spek, 2015) was tried. The results of this refinement are shown in the third column of Table 1. As can be seen, the SQUEEZE refinement led to slightly better $R$ values. To obtain further insight into the importance of crystal voids in this structure, the 'unSQUEEZEd' CIF file was examined using the program CrystalExplorer (Version 21.5), using the subroutine 'void' 


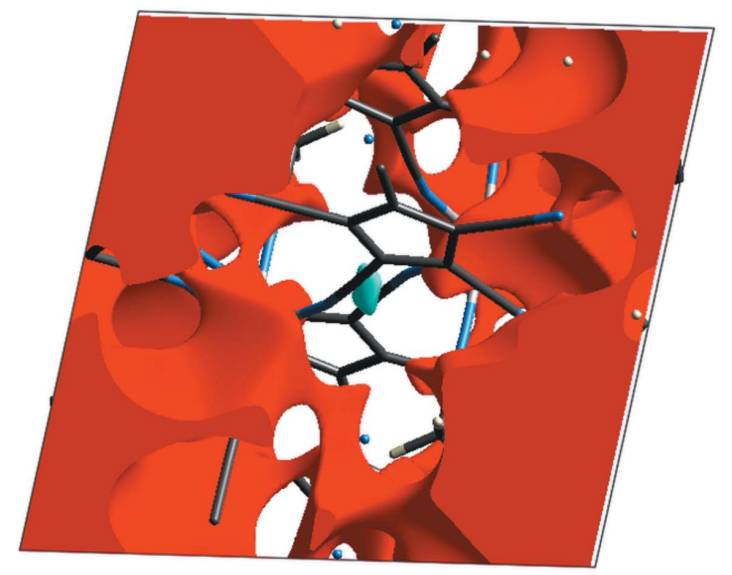

(a)

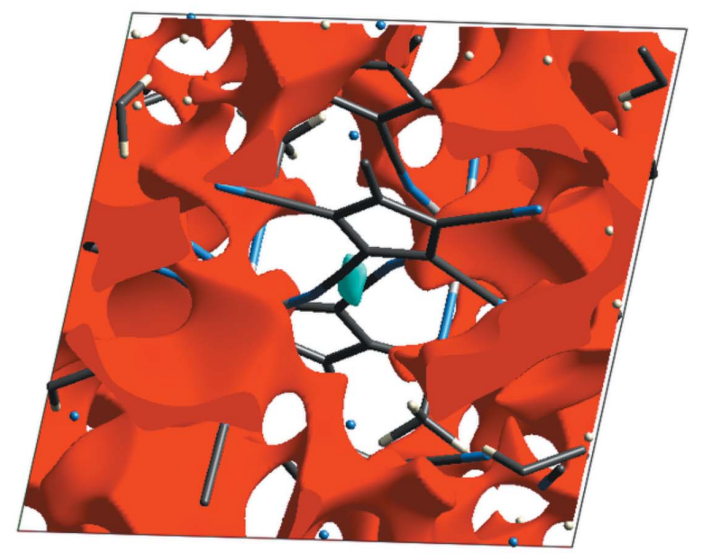

(b)

Figure 1

Crystal void plots (0.002 a.u. isosurface) of the crystal structure (a) without and $(b)$ including the $\mathrm{MeCN}$ lattice molecules.

(Turner et al., 2011), both without and with the acetonitrile molecules. Fig. 1(a) shows the void plot obtained without the $\mathrm{MeCN}$ molecules, while Fig. 1(b) shows the same plot when the MeCN molecules were included (0.002 a.u. isosurfaces; for the results of the corresponding calculations using 0.0003 a.u. isosurfaces, see Fig. S2 in the supporting information). Table 2

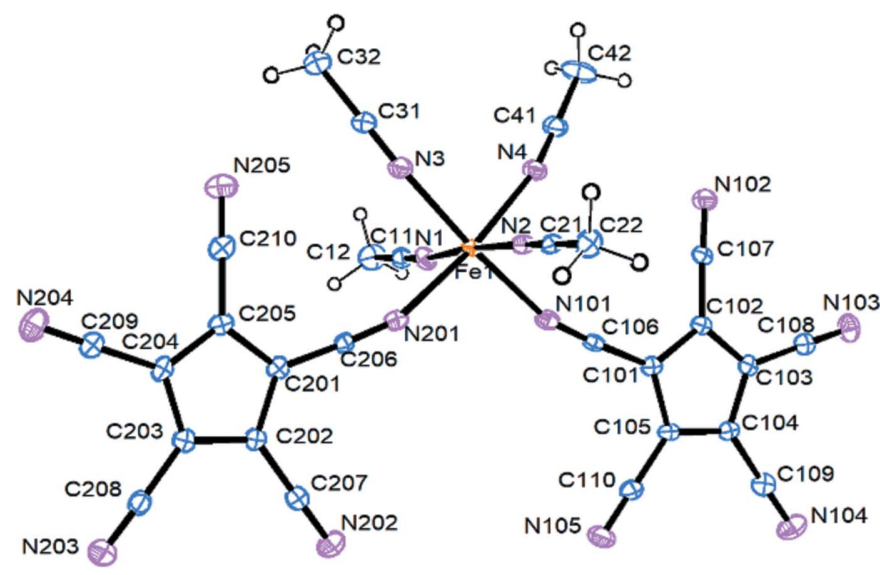

Figure 2

Displacement ellipsoid plot (30\% probability level) of (I). The lattice $\mathrm{MeCN}$ molecules are not shown.
Table 2

Comparison of the void calculations using PLATON and CrystalExplorer $(C E)$.

SASA is solvent accessible surface area (Düren et al., 2007).

\begin{tabular}{lllll}
\hline & $\begin{array}{l}\text { PLATON } \\
\text { VOID }\end{array}$ & $\begin{array}{l}\text { PLATON } \\
\text { SASA }\end{array}$ & $\begin{array}{l}\text { CE } \\
(0.002 \text { a.u. })\end{array}$ & $\begin{array}{l}\text { CE } \\
(0.0003 \text { a.u. })\end{array}$ \\
\hline $\begin{array}{l}\text { Without MeCN } \\
\text { Void volume }\end{array}$ & 346 & & & \\
Void surface & & 281 & 773.4 & 191.0 \\
With 2MeCN & & & 721.2 & 237.9 \\
Void volume & 0 & & & \\
Void surface & & 0 & 211.6 & 0.3 \\
\hline
\end{tabular}

summarizes the results of the void-space calculations using PLATON and CrystalExplorer.

As can be seen, the results obtained with PLATON (excluding the MeCN solvents) are intermediate between the CrystalExplorer results with the two different isosurfaces, which is rather unusual (Turner et al., 2011). After inclusion of the MeCN molecules, the PLATON results and the CrystalExplorer results for a 0.0003 a.u. surface are nearly identical, and show that there are no permanent voids left after inclusion of the MeCN molecules. In view of this, together with the probable involvement of the lattice $\mathrm{MeCN}$ molecules in $\mathrm{C}-$ $\mathrm{H} \cdots \mathrm{N}$ hydrogen bonds, the SQUEEZEd structure was not examined further.

\section{Results and discussion}

The title compound crystallizes in the triclinic space group $P \overline{1}$ with one molecule in the asymmetric unit. The $\mathrm{Fe}^{\mathrm{II}}$ ion coordinates to two cis-oriented pentacyanocyclopentadienyl anions via one nitrile function each, and additionally to four acetonitrile molecules (Fig. 2).

The two cyclopentadienyl rings are coplanar [interplanar angle $=0.8(2)^{\circ}$; the average distance of atoms C201-C205 from the best plane through C101-C105 is $0.044 \pm 0.02 \AA]$.

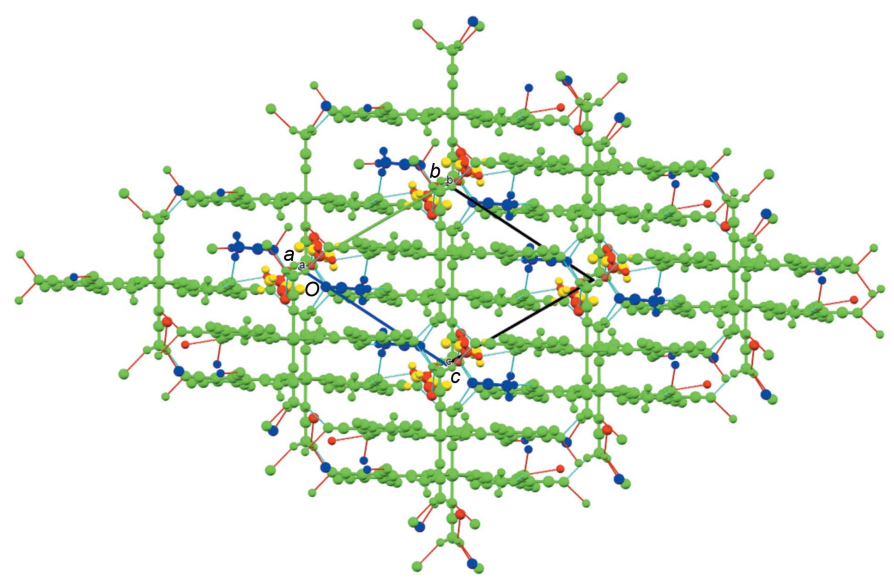

Figure 3

Packing plot (Mercury; Macrae et al., 2020), viewed along the crystallographic $a$ axis. The colour coding green/blue/yellow/red corresponds to the symmetry equivalents, as defined by Mercury. Red and blue lines show the hydrogen bonds according to Table 4 . 
Figure 4

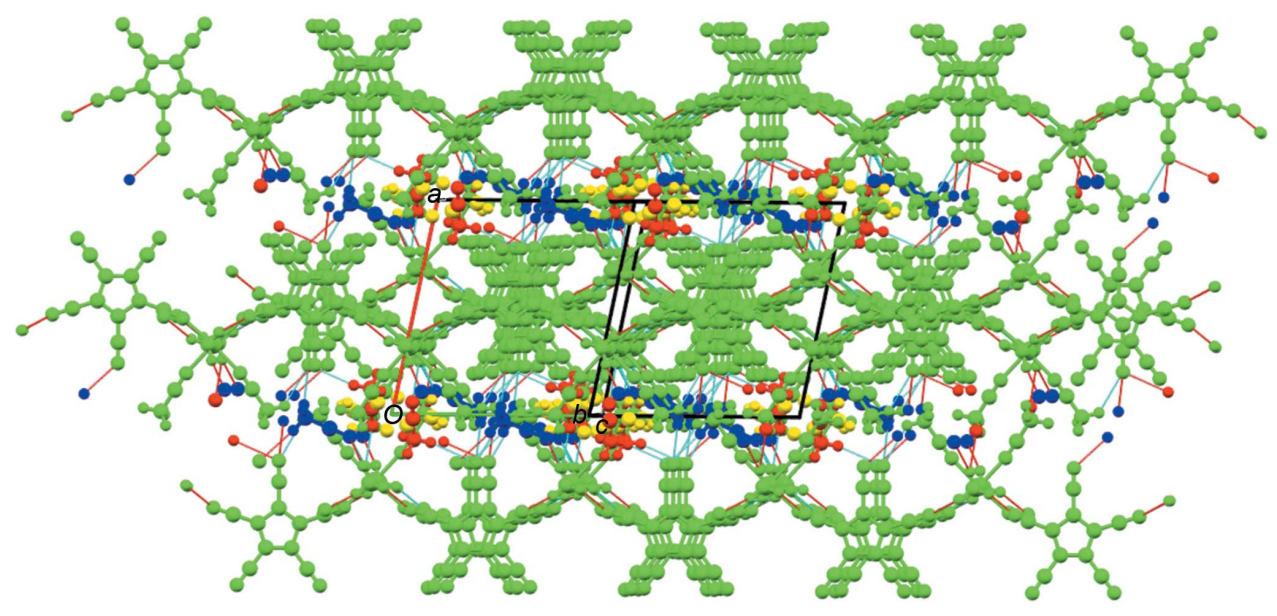

Packing plot (Mercury; Macrae et al., 2020), viewed perpendicular to the $b c$ plane. The colour coding is as in Fig. 3.

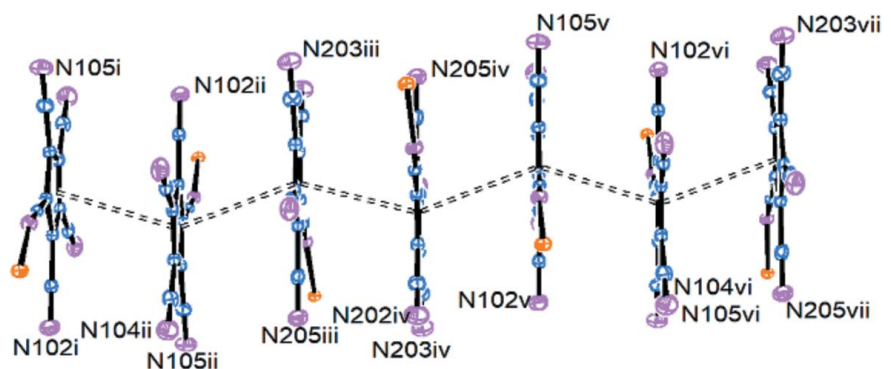

Figure 5

$\pi$-Stacking of the cyclopentadienyl rings. [Symmetry codes: (i) $x, y+1$, $z-1$; (ii) $-x+1,-y+1,-z$; (iii) $x, y, z-1$; (iv) $-x+1,-y+1,-z+1$;

(v) $x, y, z ;$ (vi) $-x+1,-y,-z+1$; (vii) $x, y-1, z$.]

The bond lengths from the $\mathrm{Fe}$ atom to the $\left[\mathrm{C}_{5}(\mathrm{CN})_{5}\right] \mathrm{N}$ atoms are significantly $(>10 \sigma)$ longer [average $2.176(3) \AA$ ] than to the acetonitrile $\mathrm{N}$ atoms [average 2.140 (4) $\AA$ ], with the bond angles at the coordinating atoms N101 and N201 close to being linear (average $161.9^{\circ}$ ). Further important bond parameters can be found in Table 3 .

Weak interactions with the contents of the voids contribute to the stability of the crystal lattice (Ghosh et al., 2019; Wang et al., 2020) and so a closer inspection of the packing plots seemed appropriate (Fig. 3).

A packing plot viewed down the crystallographic $a$ axis shows 'layers' of cyclopentadienyl rings oriented parallel to the $b c$ diagonal and orthogonal to the plane of projection. These layers contain also one of the lattice $\mathrm{MeCN}$ molecules (dark blue in Fig. 3). Individual molecules are connected via $\mathrm{C}-\mathrm{H} \cdots \mathrm{N}$ hydrogen bonds in the $b$ and $c$ directions using methyl groups $\mathrm{C} 12$ and $\mathrm{C} 22$ of the coordinated acetonitrile

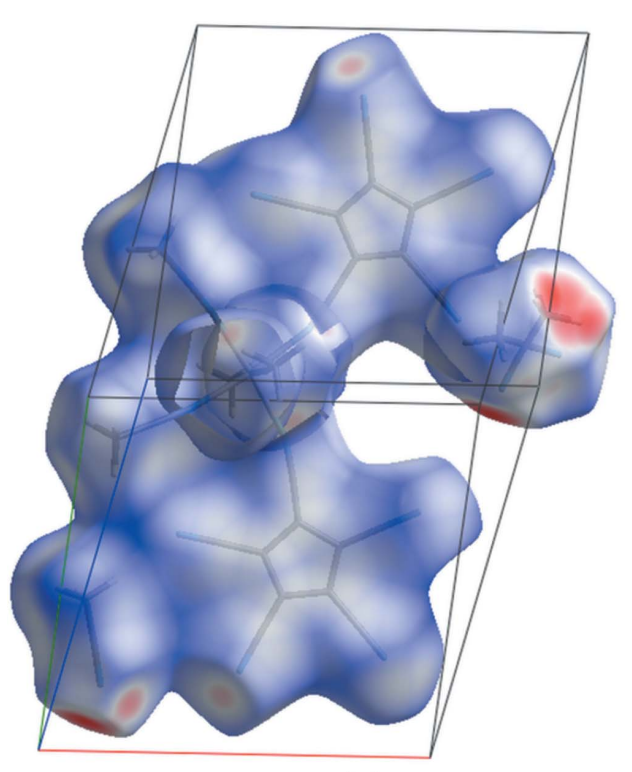

(a)

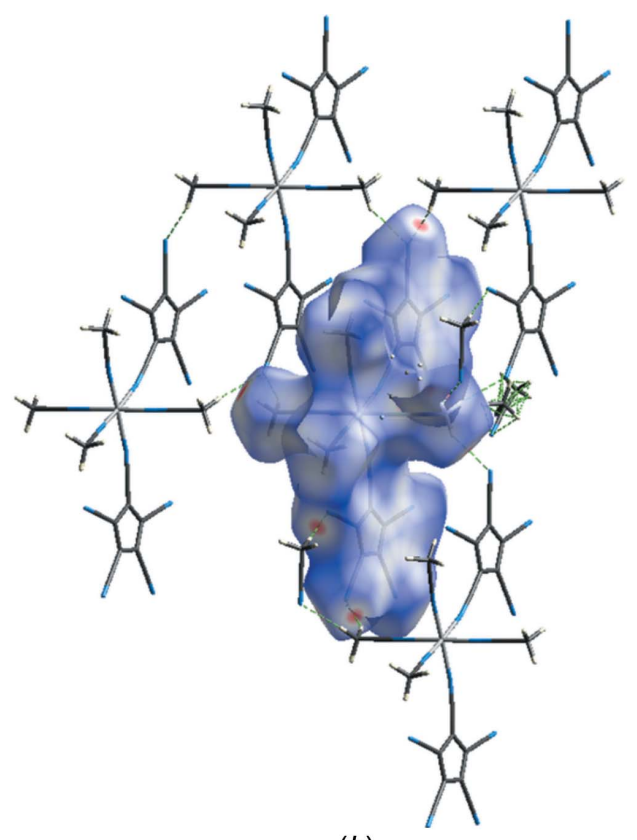

(b)

Figure 6

(a) Hirshfeld surface of the asymmetric unit of (I) using normalized contact distances $\left(d_{\text {norm }}\right)$ for colour coding. Red areas represent regions where the contact distances are significantly below the sum of the van der Waals radii. $(b)$ Hirshfeld surface of one isolated metal complex, together with some close-by neighbours, indicating also the hydrogen bridges between them and the central fragment. 
Table 3

Selected geometric parameters $\left(\AA,^{\circ}\right)$.

\begin{tabular}{lclc}
\hline $\mathrm{Fe} 1-\mathrm{N} 1$ & $2.127(3)$ & $\mathrm{Fe} 1-\mathrm{N} 4$ & $2.147(3)$ \\
$\mathrm{Fe} 1-\mathrm{N} 2$ & $2.141(3)$ & $\mathrm{Fe} 1-\mathrm{N} 101$ & $2.169(3)$ \\
$\mathrm{Fe} 1-\mathrm{N} 3$ & $2.142(3)$ & $\mathrm{Fe} 1-\mathrm{N} 201$ & $2.185(3)$ \\
& & & \\
$\mathrm{N} 1-\mathrm{Fe} 1-\mathrm{N} 2$ & $175.79(12)$ & $\mathrm{N} 101-\mathrm{Fe} 1-\mathrm{N} 201$ & $98.60(11)$ \\
$\mathrm{N} 3-\mathrm{Fe} 1-\mathrm{N} 101$ & $174.68(12)$ & $\mathrm{C} 106-\mathrm{N} 101-\mathrm{Fe} 1$ & $162.4(3)$ \\
$\mathrm{N} 4-\mathrm{Fe} 1-\mathrm{N} 101$ & $88.04(12)$ & $\mathrm{C} 206-\mathrm{N} 201-\mathrm{Fe} 1$ & $161.2(3)$ \\
\hline
\end{tabular}

molecules (both in cis positions relative to the coordinated anions) as donors and the pentacyanocyclopentadienide atoms N103 and N204 (in the 3-position relative to the coordinated cyano $\mathrm{N}$ atom), as well as the lattice $\mathrm{MeCN}$ atoms N5 and $\mathrm{N} 6 B$, as acceptors. In addition, there is also a hydrogen bond between the lattice $\mathrm{MeCN}$ group C52 and pentacyanocyclopentadienide atom N102 (Table 4).

A possibly more important intermolecular interaction becomes visible in Fig. 4.

The pentacyanocyclopentadienyl rings stack via $\pi-\pi$ interactions (Carter-Fenk \& Herbert, 2020; Thakuria et al., 2019), with the ring planes at a typical distance of $c a 3.36 \AA$. A closer look (Fig. 5) shows that the stack is formed by alternating pairs of inversion-related C101-C105 (symmetry codes i/ii and v/vi) and C201-C205 (iii/iv) rings. The dotted 'bonds' in Fig. 5 join the ring centroids at distances of 3.575 (i/ii and v/vi), 3.580 (ii/iii, iv/v and vi/vii) and $3.597 \AA$ (iii/iv), and angles of 141.3 and $142.8^{\circ}$. This corresponds to a 'ring slippage' of ca $1.15 \AA$.

In order to gain further insight into the interactions at work, a Hirshfeld analysis was undertaken with the help of the program CrystalExplorer (Spackman et al., 2021).

Fig. 6(a) shows the Hirshfeld surface of the asymmetric unit, with the $d_{\text {norm }}$ surface property (range -0.65 to 1.30 ). The strong involvement of the lattice $\mathrm{MeCN}$ molecules in donor $\mathrm{C}-\mathrm{H} \cdots \mathrm{N}$ (top right) and acceptor $\mathrm{N} \cdots \mathrm{H}-\mathrm{C}$ (bottom left) interactions can be seen. Fig. $6(b)$ shows the Hirshfeld surface of an isolated complex fragment and its interactions
Table 4

Hydrogen-bond geometry $\left(\AA{ }^{\circ}\right)$.

\begin{tabular}{lllll}
\hline$D-\mathrm{H} \cdots A$ & $D-\mathrm{H}$ & $\mathrm{H} \cdots A$ & $D \cdots A$ & $D-\mathrm{H} \cdots A$ \\
\hline $\mathrm{C} 12-\mathrm{H} 12 A \cdots \mathrm{N} 5 A^{\text {viii }}$ & 0.98 & 2.58 & $3.454(7)$ & 149 \\
$\mathrm{C} 12-\mathrm{H} 12 B \cdots \mathrm{N} 103^{\text {viii }}$ & 0.98 & 2.54 & $3.443(6)$ & 154 \\
$\mathrm{C} 12-\mathrm{H} 12 C \cdots \mathrm{N} 204^{\text {vii }}$ & 0.98 & 2.56 & $3.469(6)$ & 154 \\
$\mathrm{C} 22-\mathrm{H} 22 A \cdots \mathrm{N} 5 A^{\text {ix }}$ & 0.98 & 2.39 & $3.308(7)$ & 156 \\
$\mathrm{C} 22-\mathrm{H} 22 A \cdots \mathrm{N} 6 B^{\text {iv }}$ & 0.98 & 2.61 & $3.41(3)$ & 138 \\
$\mathrm{C} 22-\mathrm{H} 22 B \cdots \mathrm{N} 204^{\text {iii }}$ & 0.98 & 2.52 & $3.407(5)$ & 150 \\
$\mathrm{C} 22-\mathrm{H} 22 C \cdots \mathrm{N} 103^{\text {ix }}$ & 0.98 & 2.52 & $3.424(6)$ & 154 \\
$\mathrm{C} 52-\mathrm{H} 52 B \cdots \mathrm{N} 102$ & 0.98 & 2.51 & $3.492(8)$ & 176 \\
\hline
\end{tabular}

Symmetry codes: (iii) $x, y, z-1$; (iv) $-x+1,-y+1,-z+1$; (vii) $x, y-1, z$; (viii) $x, y, z+1 ;$ (ix) $x, y+1, z$.

with four further complex fragments and a few lattice MeCN molecules. In Fig. 7, the same surface showing the properties 'curvedness', 'shape index' and 'electrostatic potential' is displayed.

Both the 'curvedness' and the 'shape index' plots show the importance of planar $\pi$-stacking for both cyclopentadienyl rings (Spackman \& Jayatilaka, 2009). Fig. 7(c) shows that the asymmetric unit contains both electropositive (blue) and electronegative (red) parts, together with small neutral (white)
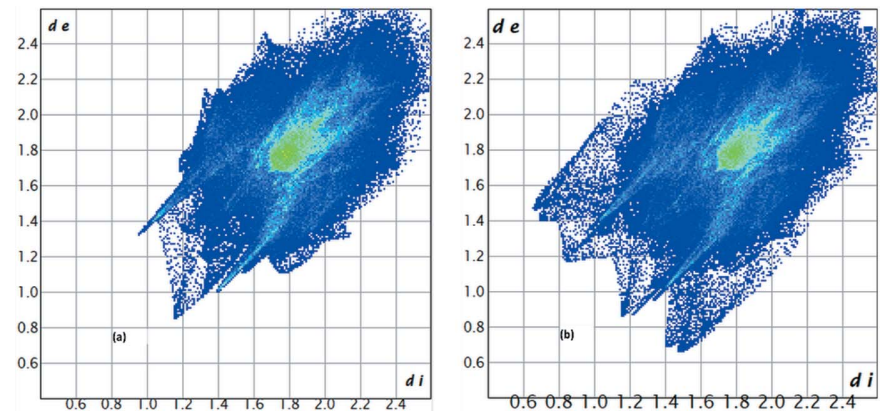

Figure 8

Fingerprint plots $(a)$ for a Hirshfeld surface enclosing only the iron complex and $(b)$ for the whole asymmetric unit.

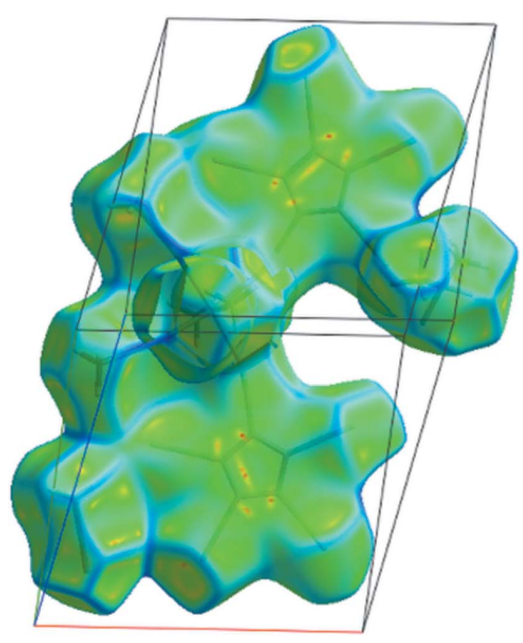

(a)

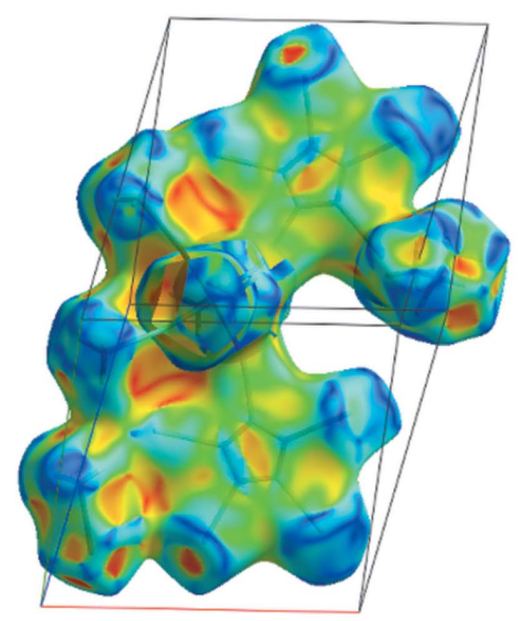

(b)

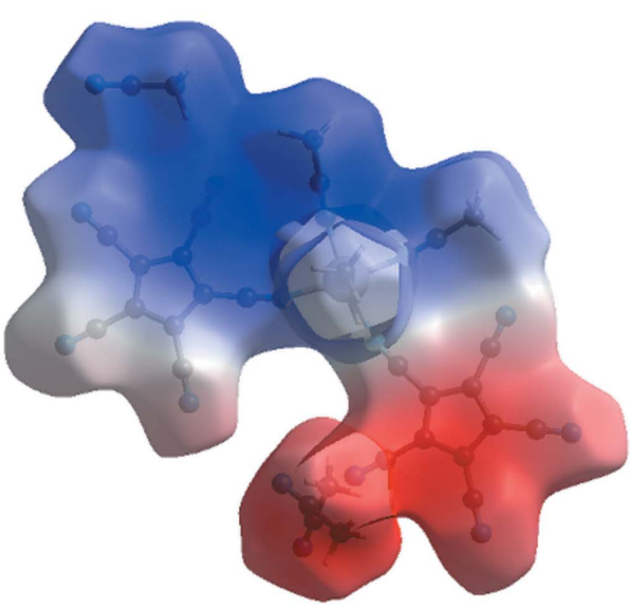

(c)

Figure 7

Hirshfeld surfaces displaying the properties (a) 'curvedness', $(b)$ 'shape index' and $(c)$ 'electrostatic potential'. 

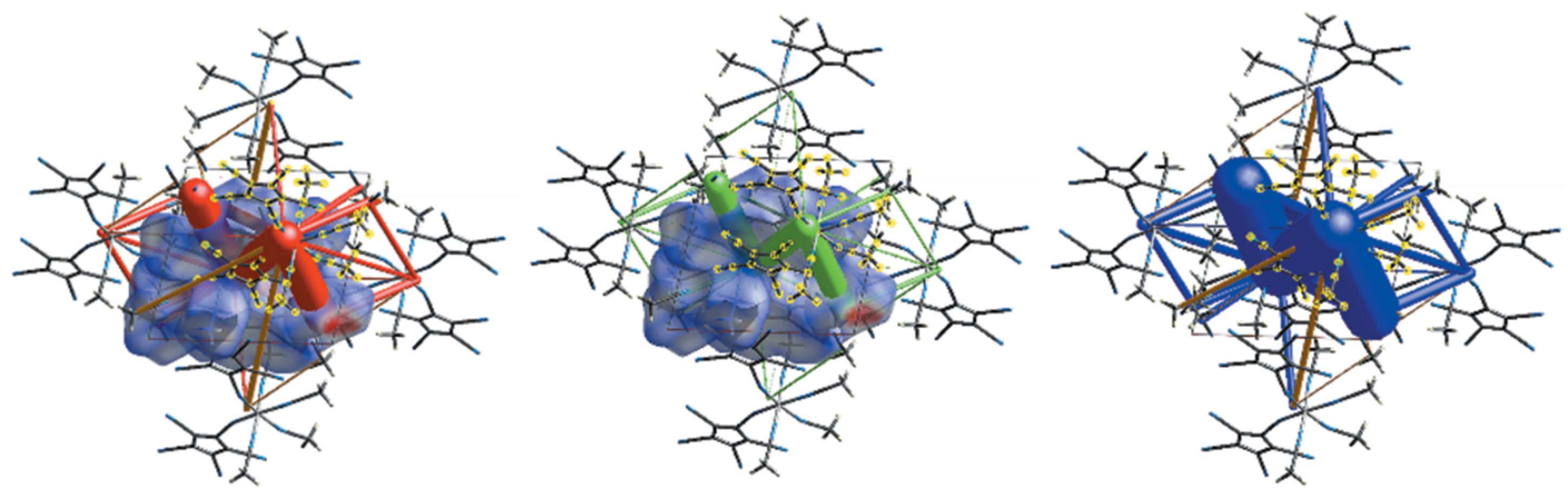

Figure 9

Energy frameworks, showing Coulombic (left) and dispersion (middle) terms, as well as total interaction energies (right).

areas. Fig. S3 (see supporting information) shows how in neighbouring molecules the positive and negative parts approach each other.

The so-called 'fingerprints' are a graphical representation of all the interactions of atoms 'inside' and 'outside' the Hirshfeld surface (Spackman \& McKinnon, 2002). Fig. 8(a) shows such a plot when the two lattice $\mathrm{MeCN}$ molecules are left outside the Hirshfeld surface, while Fig. 8(b) represents such a plot when the complete asymmetric unit is inside the Hirshfeld surface. A plot showing the most important individual contributors is shown in Fig. S4 (see supporting information). The bright-green spots at $c a(1.8 / 1.8) \AA$ in Fig. 8 correspond to $\pi-\pi$ stacking interactions; inspection of Fig. S4 shows that C. . C interactions are responsible for $\mathrm{ca} 18 \%$ of all the intermolecular interactions, while $\mathrm{C}-\mathrm{H} \cdots \pi$ interactions make up less than $7 \%$. C $-\mathrm{H} \cdots \mathrm{N}$ contacts make up nearly $50 \%$ of the weak interactions.

A last important point relates to the interaction energies in the crystal. Fig. S5 (see supporting information) shows that the interactions between the complex and the two unique $\mathrm{MeCN}$ solvent molecules are relatively weak, with the repulsive terms dominating. The interactions between the asymmetric unit and four close neighbours are displayed in Fig. S6. The energies range from -54 to $-174 \mathrm{~kJ} \mathrm{~mol}^{-1}$. The strongest interaction occurs for the closest approach of two inversionrelated molecules (magenta), with a clear dominance of the dispersion term. Another method for graphically representing these interactions is through the use of 'energy frameworks' (Turner et al., 2015), which are displayed in Fig. 9.

\section{Conclusion}

The primary reaction product from $\mathrm{FeCl}_{2}$ and $\mathrm{Ag}\left[\mathrm{C}_{5}(\mathrm{CN})_{5}\right]$ in acetonitrile is neither a 'ferrocene' nor a coordination polymer. The structure determination presented here shows a mononuclear octahedral coordination compound with two cisoriented monodentate pentacyanocyclopentadienide anions and four acetonitrile ligands. The individual molecules interact in the lattice via weak $\mathrm{C}-\mathrm{H} \cdots \mathrm{N}$ hydrogen bonds and displaced parallel cyclopentadienyl $\pi$-systems. In the absence of any crystals it is difficult to speculate about the structure of the compound ' $\mathrm{Fe}\left[\mathrm{C}_{5}(\mathrm{CN})_{5}\right]_{2} \cdot x \mathrm{H}_{2} \mathrm{O}$ ' described over 50 years ago. However, one could imagine that after removal of all the acetonitrile molecules, the remaining fragments approach each other parallel to the $b c$ plane and form 'ribbons' of $\mathrm{Fe}\left[\mathrm{C}_{5}(\mathrm{CN})_{5}\right]_{4 / 2}$ with the anions using two of their cyano groups, similar to the structure of $\mathrm{Ca}\left[\mathrm{C}_{5}(\mathrm{CN})_{4} \mathrm{H}\right]_{2} \cdot 4 \mathrm{H}_{2} \mathrm{O}$ (Sünkel \& Nimax, 2018). In contrast to the Ca compound, the Fe compound would have to be octahedrally coordinated with two additional bridging $\mathrm{H}_{2} \mathrm{O}$ ligands (Fig. 10).

\section{Acknowledgements}

Open access funding enabled and organized by Projekt DEAL.

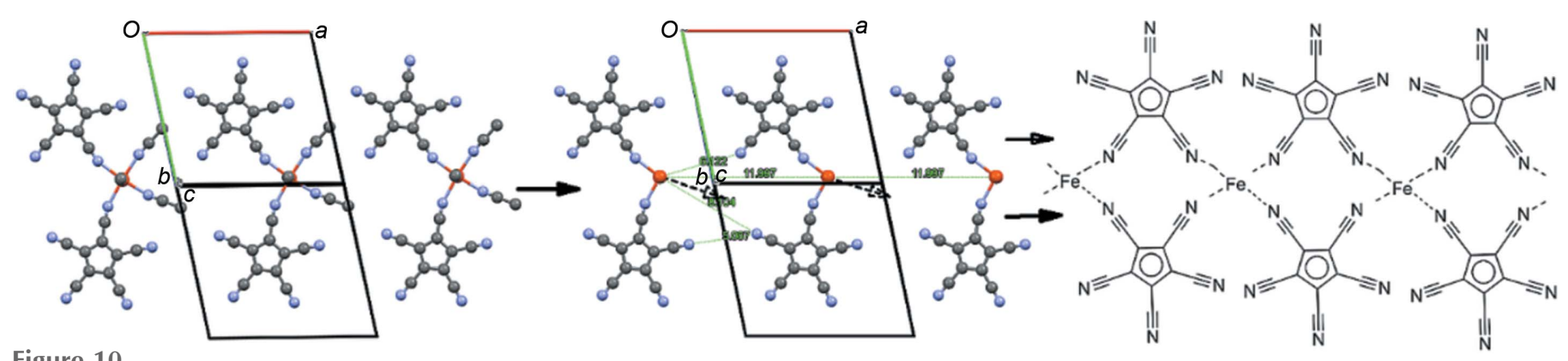

Figure 10

Suggested transformation from the title compound to a polymeric structure: (left) three molecules along the $a$ direction; (middle) the same part of the structure with the $\mathrm{MeCN}$ molecules omitted; (right) sketch of the suggested polymer (without the bridging water ligands). 


\section{References}

Bacsa, J., Less, R. J., Skelton, H. E., Soracevic, Z., Steiner, A., Wilson, T. C., Wood, P. T. \& Wright, D. S. (2011). Angew. Chem. Int. Ed. 50, 8279-8282.

Blockhaus, T. \& Sünkel, K. (2021). Z. Anorg. Allg. Chem. 647, 18491854.

Bruker (2011). APEX2 and SAINT. Bruker AXS Inc., Madison, Wisconsin, USA.

Carter-Fenk, K. \& Herbert, J. M. (2020). Phys. Chem. Chem. Phys. 22, 24870-24886.

Christopher, R. E. \& Venanzi, L. M. (1973). Inorg. Chim. Acta, 7, 489-492.

Düren, T., Millange, F., Férey, G., Walton, K. S. \& Snurr, R. Q. (2007). J. Phys. Chem. C, 111, 15350-15356.

Ghosh, A. K., Hazra, A., Mondal, A. \& Banerjee, P. (2019). Inorg. Chim. Acta, 488, 86-119.

Krause, L., Herbst-Irmer, R., Sheldrick, G. M. \& Stalke, D. (2015). J. Appl. Cryst. 48, 3-10.

Less, R. J., Wilson, T. C., Guan, B., McPartlin, M., Steiner, A., Wood, P. T. \& Wright, D. S. (2013). Eur. J. Inorg. Chem. 2013, 1161-1169.

Macrae, C. F., Sovago, I., Cottrell, S. J., Galek, P. T. A., McCabe, P., Pidcock, E., Platings, M., Shields, G. P., Stevens, J. S., Towler, M. \& Wood, P. A. (2020). J. Appl. Cryst. 53, 226-235.

Nimax, P. R., Reimann, D. \& Sünkel, K. (2018). Dalton Trans. 47, 8476-8482.
Sheldrick, G. M. (2015a). Acta Cryst. A71, 3-8.

Sheldrick, G. M. (2015b). Acta Cryst. C71, 3-8.

Spackman, M. A. \& Jayatilaka, D. (2009). CrystEngComm, 11, $19-32$.

Spackman, M. A. \& McKinnon, J. J. (2002). CrystEngComm, 4, 378392.

Spackman, P. R., Turner, M. J., McKinnon, J. J., Wolff, S. K., Grimwood, D. J., Jayatilaka, D. \& Spackman, M. A. (2021). J. Appl. Cryst. 54, 1006-1011.

Spek, A. L. (2015). Acta Cryst. C71, 9-18.

Spek, A. L. (2020). Acta Cryst. E76, 1-11.

Sünkel, K. \& Nimax, P. (2018). Dalton Trans. 47, 409-417.

Sünkel, K. \& Reimann, D. (2013). Z. Naturforsch. B, 68, 546-550.

Sünkel, K., Reimann, D. \& Nimax, P. R. (2019). Z. Naturforsch. B, 74, 109-118.

Thakuria, R., Nath, N. K. \& Saha, B. K. (2019). Cryst. Growth Des. 19 , 523-528.

Turner, M. J., McKinnon, J. J., Jayatilaka, D. \& Spackman, M. A. (2011). CrystEngComm, 13, 1804-1813.

Turner, M. J., Thomas, S. P., Shi, M. W., Jayatilaka, D. \& Spackman, M. A. (2015). Chem. Commun. 51, 3735-3738.

Wang, B., Lin, R.-B., Zhang, Z., Xiang, S. \& Chen, B. (2020). J. Am. Chem. Soc. 142, 14399-14416.

Webster, O. W. (1966). J. Am. Chem. Soc. 88, 4055-4060.

Webster, O. W. (1970). US 3536694 A 19701027.

Webster, O. W. (1974). US 3853943 A 19741210. 


\section{supporting information}

Acta Cryst. (2022). C78, 94-100 [https://doi.org/10.1107/S2053229622000365]

\section{Coordination chemistry of polynitriles. Part 9. Decacyanoferrocene revisited: crystal and molecular structure of cis- $\left[\left\{\mathrm{C}_{5}(\mathrm{CN})_{5}\right\}_{2}(\mathrm{MeCN})_{4} \mathrm{Fe}\right]$}

\section{Karlheinz Sünkel and Tobias Blockhaus}

Computing details

Data collection: APEX2 (Bruker, 2011); cell refinement: APEX2 (Bruker, 2011); data reduction: SAINT (Bruker, 2011); program(s) used to solve structure: SHELXT2014 (Sheldrick, 2015a); program(s) used to refine structure: SHELXL2018 (Sheldrick, 2015b); molecular graphics: Mercury (Macrae et al., 2020); software used to prepare material for publication: SHELXL2018 (Sheldrick, 2015b).

Tetrakis(acetonitrile- $\kappa \mathrm{N}$ ) bis(pentacyanocyclopentadienido- $\kappa \mathrm{N}$ )iron(II) acetonitrile disolvate

\section{Crystal data}

$\left[\mathrm{Fe}\left(\mathrm{C}_{10} \mathrm{~N}_{5}\right)_{2}\left(\mathrm{C}_{2} \mathrm{H}_{3} \mathrm{~N}\right)_{4}\right] \cdot 1.8 \mathrm{C}_{2} \mathrm{H}_{3} \mathrm{~N}$

$M_{r}=674.29$

Triclinic, $P \overline{1}$

$a=11.9972(7) \AA$

$b=12.8711(7) \AA$

$c=13.0907(8) \AA$

$\alpha=62.528(2)^{\circ}$

$\beta=82.929(2)^{\circ}$

$\gamma=77.210(2)^{\circ}$

$V=1748.47(18) \AA^{3}$

\section{Data collection}

Bruker D8 Venture diffractometer

Radiation source: rotating anode generator Detector resolution: 7.391 pixels $\mathrm{mm}^{-1}$ mix of $\omega$ and phi scans Absorption correction: multi-scan

(SADABS; Krause et al., 2015)

$T_{\min }=0.616, T_{\max }=0.745$

Refinement

Refinement on $F^{2}$

Least-squares matrix: full

$R\left[F^{2}>2 \sigma\left(F^{2}\right)\right]=0.064$

$w R\left(F^{2}\right)=0.163$

$S=1.02$

7081 reflections

464 parameters

3 restraints

Primary atom site location: dual
$Z=2$

$F(000)=696$

$D_{\mathrm{x}}=1.296 \mathrm{Mg} \mathrm{m}^{-3}$

Mo $K \alpha$ radiation, $\lambda=0.71073 \AA$

Cell parameters from 8142 reflections

$\theta=2.7-26.5^{\circ}$

$\mu=0.48 \mathrm{~mm}^{-1}$

$T=109 \mathrm{~K}$

Block, colourless

$0.05 \times 0.04 \times 0.03 \mathrm{~mm}$

17051 measured reflections

7081 independent reflections

5145 reflections with $I>2 \sigma(I)$

$R_{\text {int }}=0.042$

$\theta_{\text {max }}=26.4^{\circ}, \theta_{\text {min }}=3.0^{\circ}$

$h=-14 \rightarrow 13$

$k=-16 \rightarrow 14$

$l=-16 \rightarrow 16$

Hydrogen site location: inferred from neighbouring sites

$\mathrm{H}$-atom parameters constrained

$w=1 /\left[\sigma^{2}\left(F_{\mathrm{o}}^{2}\right)+(0.0525 P)^{2}+4.4167 P\right]$

where $P=\left(F_{\mathrm{o}}{ }^{2}+2 F_{\mathrm{c}}{ }^{2}\right) / 3$

$(\Delta / \sigma)_{\max }<0.001$

$\Delta \rho_{\max }=0.81 \mathrm{e} \AA^{-3}$

$\Delta \rho_{\min }=-0.63$ e $\AA^{-3}$ 


\section{Special details}

Geometry. All esds (except the esd in the dihedral angle between two 1.s. planes) are estimated using the full covariance matrix. The cell esds are taken into account individually in the estimation of esds in distances, angles and torsion angles; correlations between esds in cell parameters are only used when they are defined by crystal symmetry. An approximate (isotropic) treatment of cell esds is used for estimating esds involving l.s. planes.

Fractional atomic coordinates and isotropic or equivalent isotropic displacement parameters $\left(\AA^{2}\right)$

\begin{tabular}{|c|c|c|c|c|c|}
\hline & $x$ & $y$ & $z$ & $U_{\text {iso }} * / U_{\text {eq }}$ & Occ. $(<1)$ \\
\hline $\mathrm{Fe} 1$ & $0.31525(4)$ & $0.41288(5)$ & $0.62909(5)$ & $0.02179(16)$ & \\
\hline C101 & $0.5159(3)$ & 0.1898 & $0.4444(3)$ & $0.0220(8)$ & \\
\hline C102 & $0.4447(3)$ & 0.1551 & $0.3921(3)$ & $0.0227(8)$ & \\
\hline C103 & $0.5156(3)$ & 0.0879 & $0.3416(3)$ & $0.0241(8)$ & \\
\hline C104 & $0.6307(3)$ & $0.0814(3)$ & $0.3624(3)$ & $0.0240(8)$ & \\
\hline $\mathrm{C} 105$ & $0.6311(3)$ & $0.1436(3)$ & $0.4257(3)$ & $0.0230(8)$ & \\
\hline C106 & $0.4747(3)$ & 0.2595 & $0.5041(3)$ & $0.0208(8)$ & \\
\hline C107 & 0.3223 & 0.1848 & 0.3910 & $0.0230(8)$ & \\
\hline C108 & $0.4783(3)$ & $0.0347(3)$ & $0.2808(3)$ & $0.0277(9)$ & \\
\hline C109 & 0.7278 & 0.0216 & 0.3229 & $0.0322(9)$ & \\
\hline C110 & $0.7303(3)$ & 0.1586 & $0.4649(3)$ & $0.0273(8)$ & \\
\hline N101 & 0.4360 & 0.3168 & $0.5504(3)$ & $0.0266(7)$ & \\
\hline N102 & 0.2255 & 0.2088 & $0.3873(3)$ & $0.0368(8)$ & \\
\hline N103 & $0.4496(3)$ & $-0.0092(3)$ & $0.2322(3)$ & $0.0411(9)$ & \\
\hline N104 & 0.8048 & -0.0262 & $0.2907(4)$ & $0.0484(10)$ & \\
\hline N105 & $0.8099(3)$ & 0.1701 & $0.4953(3)$ & $0.0400(9)$ & \\
\hline C201 & 0.5149 & $0.5561(3)$ & $0.8071(3)$ & $0.0221(8)$ & \\
\hline $\mathrm{C} 202$ & 0.6298 & 0.5503 & 0.8270 & $0.0214(7)$ & \\
\hline $\mathrm{C} 203$ & 0.6296 & 0.6124 & 0.8915 & $0.0241(8)$ & \\
\hline $\mathrm{C} 204$ & $0.5152(3)$ & $0.6567(3)$ & $0.9116(3)$ & $0.0224(8)$ & \\
\hline $\mathrm{C} 205$ & $0.4442(3)$ & $0.6224(3)$ & $0.8594(3)$ & $0.0229(8)$ & \\
\hline $\mathrm{C} 206$ & $0.4744(3)$ & $0.5066(3)$ & 0.7450 & $0.0197(7)$ & \\
\hline $\mathrm{C} 207$ & $0.7275(3)$ & $0.4903(3)$ & $0.7878(3)$ & $0.0284(9)$ & \\
\hline $\mathrm{C} 208$ & $0.7274(3)$ & $0.6301(4)$ & $0.9295(3)$ & $0.0297(9)$ & \\
\hline C209 & 0.4768 & 0.7244 & 0.9745 & $0.0256(8)$ & \\
\hline $\mathrm{C} 210$ & 0.3214 & $0.6506(3)$ & 0.8589 & $0.0271(8)$ & \\
\hline N201 & $0.4370(2)$ & $0.4697(3)$ & 0.6948 & $0.0249(7)$ & \\
\hline N202 & $0.8045(3)$ & $0.4424(3)$ & $0.7558(3)$ & $0.0424(9)$ & \\
\hline N203 & $0.8046(3)$ & $0.6454(4)$ & 0.9608 & $0.0432(9)$ & \\
\hline N204 & 0.4457 & 0.7775 & $1.0254(3)$ & $0.0374(8)$ & \\
\hline N205 & 0.2240 & 0.6733 & $0.8597(3)$ & $0.0396(9)$ & \\
\hline $\mathrm{C} 11$ & $0.3267(3)$ & 0.1710 & $0.8712(3)$ & $0.0278(8)$ & \\
\hline $\mathrm{C} 12$ & $0.3231(4)$ & $0.0659(4)$ & $0.9790(4)$ & $0.0449(11)$ & \\
\hline $\mathrm{H} 12 \mathrm{~A}$ & 0.244664 & 0.067321 & 1.010643 & $0.067 *$ & \\
\hline H12B & 0.373736 & 0.064058 & 1.033356 & $0.067 *$ & \\
\hline $\mathrm{H} 12 \mathrm{C}$ & 0.348369 & -0.005159 & 0.966392 & $0.067^{*}$ & \\
\hline N1 & 0.3295 & $0.2534(3)$ & 0.7868 & $0.0282(7)$ & \\
\hline $\mathrm{C} 21$ & 0.3161 & $0.6547(3)$ & 0.3858 & $0.0237(8)$ & \\
\hline $\mathrm{C} 22$ & $0.3187(3)$ & 0.7613 & 0.2786 & $0.0312(9)$ & \\
\hline
\end{tabular}




\begin{tabular}{|c|c|c|c|c|c|}
\hline $\mathrm{H} 22 \mathrm{~A}$ & 0.242481 & 0.811730 & 0.264213 & $0.047^{*}$ & \\
\hline H22B & 0.341848 & 0.739396 & 0.215613 & $0.047^{*}$ & \\
\hline $\mathrm{H} 22 \mathrm{C}$ & 0.373587 & 0.805056 & 0.283309 & $0.047^{*}$ & \\
\hline $\mathrm{N} 2$ & $0.3143(2)$ & $0.5717(3)$ & 0.4700 & $0.0221(7)$ & \\
\hline $\mathrm{C} 31$ & $0.1095(3)$ & $0.5236(5)$ & $0.7567(4)$ & $0.0414(11)$ & \\
\hline $\mathrm{C} 32$ & $0.0114(4)$ & $0.5511(7)$ & $0.8237(5)$ & $0.074(2)$ & \\
\hline H32A & -0.051168 & 0.604249 & 0.771923 & $0.111^{*}$ & \\
\hline H32B & 0.033202 & 0.590484 & 0.864863 & $0.111^{*}$ & \\
\hline $\mathrm{H} 32 \mathrm{C}$ & -0.013764 & 0.477224 & 0.879337 & $0.111^{*}$ & \\
\hline N3 & $0.1842(3)$ & $0.4997(3)$ & 0.7056 & $0.0312(8)$ & \\
\hline $\mathrm{C} 41$ & $0.1027(3)$ & $0.3251(4)$ & 0.5766 & $0.0318(9)$ & \\
\hline C42 & $0.0031(4)$ & $0.2794(4)$ & $0.5752(5)$ & $0.0534(14)$ & \\
\hline $\mathrm{H} 42 \mathrm{~A}$ & -0.011193 & 0.217475 & 0.652389 & $0.080^{*}$ & \\
\hline H42B & 0.016765 & 0.245291 & 0.520520 & $0.080^{*}$ & \\
\hline $\mathrm{H} 42 \mathrm{C}$ & -0.063456 & 0.344381 & 0.551764 & $0.080^{*}$ & \\
\hline N4 & $0.1806(3)$ & $0.3617(3)$ & 0.5788 & $0.0296(7)$ & \\
\hline C51A & $0.0708(5)$ & $0.0441(6)$ & $0.2401(6)$ & $0.0497(16)$ & 0.8 \\
\hline C52A & $0.0220(6)$ & $0.1035(7)$ & $0.3094(7)$ & $0.073(2)$ & 0.8 \\
\hline H52A & -0.038353 & 0.170740 & 0.266821 & $0.109 *$ & 0.8 \\
\hline H52B & 0.081554 & 0.132953 & 0.327960 & $0.109^{*}$ & 0.8 \\
\hline $\mathrm{H} 52 \mathrm{C}$ & -0.010596 & 0.047408 & 0.380848 & $0.109^{*}$ & 0.8 \\
\hline N5A & $0.1071(5)$ & $-0.0057(6)$ & $0.1860(5)$ & $0.0666(17)$ & 0.8 \\
\hline C61A & $0.9780(6)$ & $0.1859(7)$ & $0.9281(6)$ & $0.0515(18)$ & 0.8 \\
\hline C62A & $0.8810(6)$ & $0.1424(6)$ & $0.9942(6)$ & $0.0573(18)$ & 0.8 \\
\hline H62A & 0.868264 & 0.162584 & 1.058788 & $0.086^{*}$ & 0.8 \\
\hline H62B & 0.894014 & 0.055574 & 1.023800 & $0.086^{*}$ & 0.8 \\
\hline H62C & 0.813699 & 0.178828 & 0.945575 & $0.086^{*}$ & 0.8 \\
\hline N6A & $1.0559(6)$ & $0.2234(7)$ & $0.8743(7)$ & 0.095 (3) & 0.8 \\
\hline N6B & $0.921(3)$ & $0.115(3)$ & $0.881(2)$ & $0.091(9)^{*}$ & 0.2 \\
\hline C61B & $0.944(5)$ & $0.147(5)$ & 0.944 (4) & $0.095(18)^{*}$ & 0.2 \\
\hline C62B & $0.984(3)$ & $0.176(3)$ & $1.025(3)$ & $0.074(9)^{*}$ & 0.2 \\
\hline H62D & 0.930033 & 0.242670 & 1.030072 & $0.111^{*}$ & 0.2 \\
\hline H62E & 0.989632 & 0.106186 & 1.100870 & $0.111^{*}$ & 0.2 \\
\hline $\mathrm{H} 62 \mathrm{~F}$ & 1.059168 & 0.197529 & 0.999519 & $0.111^{*}$ & 0.2 \\
\hline
\end{tabular}

Atomic displacement parameters $\left(\AA^{2}\right)$

\begin{tabular}{lllllll}
\hline & $U^{11}$ & $U^{22}$ & $U^{33}$ & $U^{12}$ & $U^{13}$ & $U^{23}$ \\
\hline Fe1 & $0.0159(3)$ & $0.0225(3)$ & $0.0240(3)$ & $-0.00369(19)$ & $-0.00088(19)$ & $-0.0078(2)$ \\
C101 & $0.0223(18)$ & $0.0172(17)$ & $0.0206(19)$ & $-0.0047(14)$ & $0.0005(14)$ & $-0.0034(15)$ \\
C102 & $0.0221(18)$ & $0.0194(17)$ & $0.0195(18)$ & $-0.0068(14)$ & $-0.0014(14)$ & $-0.0013(15)$ \\
C103 & $0.028(2)$ & $0.0203(18)$ & $0.0173(18)$ & $-0.0070(15)$ & $-0.0005(14)$ & $-0.0013(15)$ \\
C104 & $0.0233(19)$ & $0.0186(18)$ & $0.0220(19)$ & $-0.0036(14)$ & $0.0009(14)$ & $-0.0030(15)$ \\
C105 & $0.0185(18)$ & $0.0187(18)$ & $0.0240(19)$ & $-0.0034(14)$ & $-0.0006(14)$ & $-0.0030(15)$ \\
C106 & $0.0160(17)$ & $0.0179(18)$ & $0.0221(19)$ & $-0.0070(14)$ & $-0.0029(13)$ & $-0.0013(16)$ \\
C107 & $0.022(2)$ & $0.0211(19)$ & $0.0210(19)$ & $-0.0062(14)$ & $-0.0026(14)$ & $-0.0038(16)$ \\
C108 & $0.031(2)$ & $0.022(2)$ & $0.022(2)$ & $-0.0058(16)$ & $-0.0009(15)$ & $-0.0028(17)$ \\
C109 & $0.034(2)$ & $0.025(2)$ & $0.032(2)$ & $-0.0040(17)$ & $-0.0023(17)$ & $-0.0085(18)$
\end{tabular}




\begin{tabular}{|c|c|c|c|c|c|c|}
\hline $\mathrm{C} 110$ & $0.023(2)$ & $0.026(2)$ & $0.029(2)$ & $-0.0016(15)$ & $0.0010(15)$ & $-0.0108(17)$ \\
\hline N101 & $0.0226(16)$ & $0.0238(17)$ & $0.0298(18)$ & $-0.0072(13)$ & $-0.0034(13)$ & $-0.0072(15)$ \\
\hline N102 & $0.027(2)$ & $0.046(2)$ & $0.035(2)$ & $-0.0076(16)$ & $0.0002(14)$ & $-0.0162(18)$ \\
\hline N103 & $0.054(2)$ & $0.037(2)$ & $0.030(2)$ & $-0.0131(18)$ & $-0.0037(17)$ & $-0.0108(17)$ \\
\hline N104 & $0.039(2)$ & $0.044(2)$ & $0.057(3)$ & $-0.0002(18)$ & $0.0095(19)$ & $-0.024(2)$ \\
\hline N105 & $0.0266(19)$ & $0.047(2)$ & $0.053(2)$ & $-0.0044(16)$ & $-0.0078(16)$ & $-0.027(2)$ \\
\hline C201 & $0.0260(19)$ & $0.0164(17)$ & $0.0183(18)$ & $-0.0061(14)$ & $0.0017(14)$ & $-0.0027(15)$ \\
\hline C202 & $0.0245(19)$ & $0.0172(17)$ & $0.0198(18)$ & $-0.0050(14)$ & $-0.0002(14)$ & $-0.0058(15)$ \\
\hline C203 & $0.027(2)$ & $0.0200(18)$ & 0.0209 (19) & $-0.0052(15)$ & $0.0002(14)$ & $-0.0055(16)$ \\
\hline C204 & $0.031(2)$ & $0.0150(17)$ & $0.0164(18)$ & $-0.0040(14)$ & $0.0026(14)$ & $-0.0035(14)$ \\
\hline C205 & $0.0235(19)$ & $0.0173(17)$ & $0.0205(18)$ & $-0.0045(14)$ & $0.0018(14)$ & $-0.0027(15)$ \\
\hline C206 & $0.0193(17)$ & $0.0183(17)$ & $0.0174(18)$ & $-0.0031(14)$ & $0.0026(13)$ & $-0.0056(15)$ \\
\hline C207 & $0.030(2)$ & $0.028(2)$ & $0.028(2)$ & $-0.0071(17)$ & $-0.0042(16)$ & $-0.0113(18)$ \\
\hline C208 & $0.030(2)$ & $0.032(2)$ & $0.030(2)$ & $-0.0060(17)$ & $0.0047(16)$ & $-0.0188(19)$ \\
\hline C209 & $0.030(2)$ & $0.0193(18)$ & $0.022(2)$ & $-0.0046(15)$ & $0.0011(15)$ & $-0.0056(16)$ \\
\hline $\mathrm{C} 210$ & $0.032(2)$ & $0.0183(19)$ & $0.025(2)$ & $-0.0053(15)$ & $0.0031(16)$ & $-0.0054(16)$ \\
\hline N201 & $0.0195(16)$ & $0.0255(16)$ & $0.0271(17)$ & $-0.0039(12)$ & $0.0024(12)$ & $-0.0106(15)$ \\
\hline N202 & $0.034(2)$ & $0.048(2)$ & $0.051(2)$ & $0.0022(17)$ & $0.0027(17)$ & $-0.032(2)$ \\
\hline N203 & $0.034(2)$ & $0.055(2)$ & $0.052(2)$ & $-0.0130(18)$ & $0.0019(17)$ & $-0.033(2)$ \\
\hline N204 & $0.046(2)$ & $0.0296(19)$ & $0.035(2)$ & $-0.0044(16)$ & $0.0051(16)$ & $-0.0158(17)$ \\
\hline N205 & $0.029(2)$ & $0.037(2)$ & $0.051(2)$ & $-0.0053(15)$ & $0.0016(16)$ & -0.0199 (19) \\
\hline $\mathrm{C} 11$ & $0.027(2)$ & $0.028(2)$ & $0.030(2)$ & $-0.0012(16)$ & $-0.0035(16)$ & $-0.0146(19)$ \\
\hline $\mathrm{C} 12$ & 0.047 (3) & $0.037(3)$ & $0.033(3)$ & $-0.004(2)$ & $-0.001(2)$ & $-0.002(2)$ \\
\hline N1 & $0.0305(18)$ & $0.0253(18)$ & $0.0272(19)$ & $-0.0033(14)$ & $-0.0078(13)$ & $-0.0096(16)$ \\
\hline $\mathrm{C} 21$ & $0.0157(18)$ & $0.030(2)$ & $0.028(2)$ & $-0.0006(14)$ & $0.0005(14)$ & $-0.0172(19)$ \\
\hline $\mathrm{C} 22$ & $0.034(2)$ & $0.026(2)$ & $0.028(2)$ & $-0.0054(16)$ & $0.0011(16)$ & $-0.0087(18)$ \\
\hline $\mathrm{N} 2$ & $0.0164(15)$ & $0.0231(16)$ & $0.0242(17)$ & $-0.0020(12)$ & $-0.0008(12)$ & $-0.0089(15)$ \\
\hline $\mathrm{C} 31$ & $0.021(2)$ & 0.070 & $0.041(3)$ & $-0.005(2)$ & $-0.0007(18)$ & $-0.033(3)$ \\
\hline $\mathrm{C} 32$ & $0.029(3)$ & $0.150(6)$ & $0.072(4)$ & $-0.008(3)$ & $0.005(2)$ & $-0.078(4)$ \\
\hline N3 & $0.0236(18)$ & $0.040(2)$ & $0.0282(18)$ & $-0.0073(14)$ & $-0.0007(14)$ & $-0.0127(16)$ \\
\hline $\mathrm{C} 41$ & $0.024(2)$ & $0.036(2)$ & $0.033(2)$ & $-0.0020(17)$ & $-0.0033(16)$ & -0.0143 (19) \\
\hline $\mathrm{C} 42$ & $0.030(2)$ & 0.050 & $0.077(4)$ & $-0.019(2)$ & $-0.010(2)$ & $-0.019(3)$ \\
\hline N4 & $0.0223(17)$ & $0.0348(19)$ & $0.0314(19)$ & $-0.0066(14)$ & $-0.0013(13)$ & $-0.0137(16)$ \\
\hline C51A & $0.032(3)$ & $0.043(4)$ & $0.059(4)$ & $0.001(3)$ & $-0.006(3)$ & $-0.012(3)$ \\
\hline C52A & $0.056(4)$ & $0.072(5)$ & $0.111(7)$ & $0.002(4)$ & $-0.030(4)$ & $-0.058(5)$ \\
\hline N5A & $0.045(3)$ & $0.066(4)$ & 0.055 & $0.005(3)$ & $0.006(3)$ & $-0.007(3)$ \\
\hline C61A & $0.033(4)$ & $0.042(4)$ & $0.053(4)$ & $0.011(3)$ & $-0.014(3)$ & $-0.004(3)$ \\
\hline C62A & $0.051(4)$ & $0.058(4)$ & $0.049(4)$ & $-0.005(3)$ & $0.002(3)$ & $-0.015(3)$ \\
\hline N6A & $0.049(4)$ & $0.099(6)$ & $0.095(5)$ & $-0.019(4)$ & $-0.001(4)$ & $-0.005(4)$ \\
\hline
\end{tabular}

Geometric parameters $\left(\AA,{ }^{\circ}\right)$

\begin{tabular}{llll}
\hline $\mathrm{Fe} 1-\mathrm{N} 1$ & $2.127(3)$ & $\mathrm{C} 11-\mathrm{N} 1$ & $1.128(5)$ \\
$\mathrm{Fe} 1-\mathrm{N} 2$ & $2.141(3)$ & $\mathrm{C} 11-\mathrm{C} 12$ & $1.440(6)$ \\
$\mathrm{Fe} 1-\mathrm{N} 3$ & $2.142(3)$ & $\mathrm{C} 12-\mathrm{H} 12 \mathrm{~A}$ & 0.9800 \\
$\mathrm{Fe} 1-\mathrm{N} 4$ & $2.147(3)$ & $\mathrm{C} 12-\mathrm{H} 12 \mathrm{~B}$ & 0.9800 \\
$\mathrm{Fe} 1-\mathrm{N} 101$ & $2.169(3)$ & $\mathrm{C} 12-\mathrm{H} 12 \mathrm{C}$ & 0.9800 \\
$\mathrm{Fe} 1-\mathrm{N} 201$ & $2.185(3)$ & $\mathrm{C} 21-\mathrm{N} 2$ & $1.129(5)$
\end{tabular}




\begin{tabular}{|c|c|c|c|}
\hline $\mathrm{C} 101-\mathrm{C} 102$ & $1.412(5)$ & $\mathrm{C} 21-\mathrm{C} 22$ & $1.444(5)$ \\
\hline $\mathrm{C} 101-\mathrm{C} 105$ & $1.418(5)$ & $\mathrm{C} 22-\mathrm{H} 22 \mathrm{~A}$ & 0.9800 \\
\hline $\mathrm{C} 101-\mathrm{C} 106$ & $1.420(5)$ & $\mathrm{C} 22-\mathrm{H} 22 \mathrm{~B}$ & 0.9800 \\
\hline $\mathrm{C} 102-\mathrm{C} 103$ & $1.404(5)$ & $\mathrm{C} 22-\mathrm{H} 22 \mathrm{C}$ & 0.9800 \\
\hline $\mathrm{C} 102-\mathrm{C} 107$ & $1.433(5)$ & $\mathrm{C} 31-\mathrm{N} 3$ & $1.125(5)$ \\
\hline $\mathrm{C} 103-\mathrm{C} 104$ & $1.416(5)$ & $\mathrm{C} 31-\mathrm{C} 32$ & $1.459(6)$ \\
\hline $\mathrm{C} 103-\mathrm{C} 108$ & $1.423(6)$ & $\mathrm{C} 32-\mathrm{H} 32 \mathrm{~A}$ & 0.9800 \\
\hline $\mathrm{C} 104-\mathrm{C} 105$ & $1.395(5)$ & $\mathrm{C} 32-\mathrm{H} 32 \mathrm{~B}$ & 0.9800 \\
\hline C104-C109 & $1.427(5)$ & $\mathrm{C} 32-\mathrm{H} 32 \mathrm{C}$ & 0.9800 \\
\hline $\mathrm{C} 105-\mathrm{C} 110$ & $1.435(5)$ & $\mathrm{C} 41-\mathrm{N} 4$ & $1.145(5)$ \\
\hline $\mathrm{C} 106-\mathrm{N} 101$ & $1.148(5)$ & $\mathrm{C} 41-\mathrm{C} 42$ & $1.450(6)$ \\
\hline C107-N102 & $1.135(5)$ & $\mathrm{C} 42-\mathrm{H} 42 \mathrm{~A}$ & 0.9800 \\
\hline $\mathrm{C} 108-\mathrm{N} 103$ & $1.148(5)$ & $\mathrm{C} 42-\mathrm{H} 42 \mathrm{~B}$ & 0.9800 \\
\hline $\mathrm{C} 109-\mathrm{N} 104$ & $1.141(5)$ & $\mathrm{C} 42-\mathrm{H} 42 \mathrm{C}$ & 0.9800 \\
\hline $\mathrm{C} 110-\mathrm{N} 105$ & $1.142(5)$ & $\mathrm{C} 51 \mathrm{~A}-\mathrm{N} 5 \mathrm{~A}$ & $1.149(9)$ \\
\hline $\mathrm{C} 201-\mathrm{C} 205$ & $1.411(5)$ & $\mathrm{C} 51 \mathrm{~A}-\mathrm{C} 52 \mathrm{~A}$ & $1.436(10)$ \\
\hline $\mathrm{C} 201-\mathrm{C} 202$ & $1.413(5)$ & $\mathrm{C} 52 \mathrm{~A}-\mathrm{H} 52 \mathrm{~A}$ & 0.9800 \\
\hline $\mathrm{C} 201-\mathrm{C} 206$ & $1.420(5)$ & $\mathrm{C} 52 \mathrm{~A}-\mathrm{H} 52 \mathrm{~B}$ & 0.9800 \\
\hline $\mathrm{C} 202-\mathrm{C} 203$ & $1.406(5)$ & $\mathrm{C} 52 \mathrm{~A}-\mathrm{H} 52 \mathrm{C}$ & 0.9800 \\
\hline $\mathrm{C} 202-\mathrm{C} 207$ & $1.431(5)$ & $\mathrm{C} 61 \mathrm{~A}-\mathrm{N} 6 \mathrm{~A}$ & $1.152(9)$ \\
\hline $\mathrm{C} 203-\mathrm{C} 204$ & $1.407(5)$ & $\mathrm{C} 61 \mathrm{~A}-\mathrm{C} 62 \mathrm{~A}$ & $1.418(10)$ \\
\hline $\mathrm{C} 203-\mathrm{C} 208$ & $1.429(5)$ & $\mathrm{C} 62 \mathrm{~A}-\mathrm{H} 62 \mathrm{~A}$ & 0.9800 \\
\hline $\mathrm{C} 204-\mathrm{C} 205$ & $1.406(5)$ & $\mathrm{C} 62 \mathrm{~A}-\mathrm{H} 62 \mathrm{~B}$ & 0.9800 \\
\hline C204-C209 & $1.430(5)$ & $\mathrm{C} 62 \mathrm{~A}-\mathrm{H} 62 \mathrm{C}$ & 0.9800 \\
\hline $\mathrm{C} 205-\mathrm{C} 210$ & $1.437(5)$ & $\mathrm{N} 6 \mathrm{~B}-\mathrm{C} 61 \mathrm{~B}$ & $1.155(18)$ \\
\hline $\mathrm{C} 206-\mathrm{N} 201$ & $1.146(4)$ & $\mathrm{C} 61 \mathrm{~B}-\mathrm{C} 62 \mathrm{~B}$ & $1.430(18)$ \\
\hline $\mathrm{C} 207-\mathrm{N} 202$ & $1.141(5)$ & $\mathrm{C} 62 \mathrm{~B}-\mathrm{H} 62 \mathrm{D}$ & 0.9800 \\
\hline $\mathrm{C} 208-\mathrm{N} 203$ & $1.146(5)$ & $\mathrm{C} 62 \mathrm{~B}-\mathrm{H} 62 \mathrm{E}$ & 0.9800 \\
\hline C209-N204 & $1.138(5)$ & $\mathrm{C} 62 \mathrm{~B}-\mathrm{H} 62 \mathrm{~F}$ & 0.9800 \\
\hline $\mathrm{C} 210-\mathrm{N} 205$ & $1.140(5)$ & & \\
\hline $\mathrm{N} 1-\mathrm{Fe} 1-\mathrm{N} 2$ & $175.79(12)$ & $\mathrm{N} 205-\mathrm{C} 210-\mathrm{C} 205$ & $179.1(4)$ \\
\hline $\mathrm{N} 1-\mathrm{Fe} 1-\mathrm{N} 3$ & $90.01(12)$ & $\mathrm{C} 206-\mathrm{N} 201-\mathrm{Fe} 1$ & $161.2(3)$ \\
\hline $\mathrm{N} 2-\mathrm{Fe} 1-\mathrm{N} 3$ & $92.83(12)$ & $\mathrm{N} 1-\mathrm{C} 11-\mathrm{C} 12$ & $179.9(6)$ \\
\hline $\mathrm{N} 1-\mathrm{Fe} 1-\mathrm{N} 4$ & $90.01(12)$ & $\mathrm{C} 11-\mathrm{C} 12-\mathrm{H} 12 \mathrm{~A}$ & 109.5 \\
\hline $\mathrm{N} 2-\mathrm{Fe} 1-\mathrm{N} 4$ & $93.26(12)$ & $\mathrm{C} 11-\mathrm{C} 12-\mathrm{H} 12 \mathrm{~B}$ & 109.5 \\
\hline $\mathrm{N} 3-\mathrm{Fe} 1-\mathrm{N} 4$ & $86.77(12)$ & $\mathrm{H} 12 \mathrm{~A}-\mathrm{C} 12-\mathrm{H} 12 \mathrm{~B}$ & 109.5 \\
\hline $\mathrm{N} 1-\mathrm{Fe} 1-\mathrm{N} 101$ & $88.79(12)$ & $\mathrm{C} 11-\mathrm{C} 12-\mathrm{H} 12 \mathrm{C}$ & 109.5 \\
\hline $\mathrm{N} 2-\mathrm{Fe} 1-\mathrm{N} 101$ & $88.66(11)$ & $\mathrm{H} 12 \mathrm{~A}-\mathrm{C} 12-\mathrm{H} 12 \mathrm{C}$ & 109.5 \\
\hline N3-Fe1-N101 & $174.68(12)$ & $\mathrm{H} 12 \mathrm{~B}-\mathrm{C} 12-\mathrm{H} 12 \mathrm{C}$ & 109.5 \\
\hline N4-Fe1-N101 & $88.04(12)$ & $\mathrm{C} 11-\mathrm{N} 1-\mathrm{Fe} 1$ & $173.8(3)$ \\
\hline N1-Fe1-N201 & $88.02(12)$ & $\mathrm{N} 2-\mathrm{C} 21-\mathrm{C} 22$ & $179.6(4)$ \\
\hline $\mathrm{N} 2-\mathrm{Fe} 1-\mathrm{N} 201$ & $89.04(11)$ & $\mathrm{C} 21-\mathrm{C} 22-\mathrm{H} 22 \mathrm{~A}$ & 109.5 \\
\hline $\mathrm{N} 3-\mathrm{Fe} 1-\mathrm{N} 201$ & $86.53(12)$ & $\mathrm{C} 21-\mathrm{C} 22-\mathrm{H} 22 \mathrm{~B}$ & 109.5 \\
\hline N4-Fe1-N201 & $173.02(12)$ & $\mathrm{H} 22 \mathrm{~A}-\mathrm{C} 22-\mathrm{H} 22 \mathrm{~B}$ & 109.5 \\
\hline N101-Fe1-N201 & $98.60(11)$ & $\mathrm{C} 21-\mathrm{C} 22-\mathrm{H} 22 \mathrm{C}$ & 109.5 \\
\hline $\mathrm{C} 102-\mathrm{C} 101-\mathrm{C} 105$ & $108.2(3)$ & $\mathrm{H} 22 \mathrm{~A}-\mathrm{C} 22-\mathrm{H} 22 \mathrm{C}$ & 109.5 \\
\hline $\mathrm{C} 102-\mathrm{C} 101-\mathrm{C} 106$ & $124.0(3)$ & $\mathrm{H} 22 \mathrm{~B}-\mathrm{C} 22-\mathrm{H} 22 \mathrm{C}$ & 109.5 \\
\hline
\end{tabular}




\begin{tabular}{|c|c|}
\hline $\mathrm{C} 105-\mathrm{C} 101-\mathrm{C} 106$ & $127.9(3)$ \\
\hline $\mathrm{C} 103-\mathrm{C} 102-\mathrm{C} 101$ & $107.6(3)$ \\
\hline $\mathrm{C} 103-\mathrm{C} 102-\mathrm{C} 107$ & $127.0(3)$ \\
\hline $\mathrm{C} 101-\mathrm{C} 102-\mathrm{C} 107$ & $125.4(3)$ \\
\hline $\mathrm{C} 102-\mathrm{C} 103-\mathrm{C} 104$ & $108.2(3)$ \\
\hline $\mathrm{C} 102-\mathrm{C} 103-\mathrm{C} 108$ & $125.9(3)$ \\
\hline $\mathrm{C} 104-\mathrm{C} 103-\mathrm{C} 108$ & $125.9(3)$ \\
\hline $\mathrm{C} 105-\mathrm{C} 104-\mathrm{C} 103$ & $108.3(3)$ \\
\hline $\mathrm{C} 105-\mathrm{C} 104-\mathrm{C} 109$ & $127.0(3)$ \\
\hline $\mathrm{C} 103-\mathrm{C} 104-\mathrm{C} 109$ & $124.7(4)$ \\
\hline $\mathrm{C} 104-\mathrm{C} 105-\mathrm{C} 101$ & $107.8(3)$ \\
\hline $\mathrm{C} 104-\mathrm{C} 105-\mathrm{C} 110$ & $126.2(3)$ \\
\hline $\mathrm{C} 101-\mathrm{C} 105-\mathrm{C} 110$ & $126.0(3)$ \\
\hline $\mathrm{N} 101-\mathrm{C} 106-\mathrm{C} 101$ & $176.6(4)$ \\
\hline $\mathrm{N} 102-\mathrm{C} 107-\mathrm{C} 102$ & $178.3(4)$ \\
\hline $\mathrm{N} 103-\mathrm{C} 108-\mathrm{C} 103$ & $179.1(4)$ \\
\hline $\mathrm{N} 104-\mathrm{C} 109-\mathrm{C} 104$ & $179.3(5)$ \\
\hline $\mathrm{N} 105-\mathrm{C} 110-\mathrm{C} 105$ & $179.2(4)$ \\
\hline $\mathrm{C} 106-\mathrm{N} 101-\mathrm{Fe} 1$ & $162.4(3)$ \\
\hline $\mathrm{C} 205-\mathrm{C} 201-\mathrm{C} 202$ & $107.9(3)$ \\
\hline $\mathrm{C} 205-\mathrm{C} 201-\mathrm{C} 206$ & $124.6(3)$ \\
\hline $\mathrm{C} 202-\mathrm{C} 201-\mathrm{C} 206$ & $127.5(3)$ \\
\hline $\mathrm{C} 203-\mathrm{C} 202-\mathrm{C} 201$ & $107.9(3)$ \\
\hline $\mathrm{C} 203-\mathrm{C} 202-\mathrm{C} 207$ & $127.1(3)$ \\
\hline $\mathrm{C} 201-\mathrm{C} 202-\mathrm{C} 207$ & $125.0(3)$ \\
\hline $\mathrm{C} 202-\mathrm{C} 203-\mathrm{C} 204$ & $108.0(3)$ \\
\hline $\mathrm{C} 202-\mathrm{C} 203-\mathrm{C} 208$ & $126.7(3)$ \\
\hline $\mathrm{C} 204-\mathrm{C} 203-\mathrm{C} 208$ & $125.2(3)$ \\
\hline $\mathrm{C} 205-\mathrm{C} 204-\mathrm{C} 203$ & $108.3(3)$ \\
\hline $\mathrm{C} 205-\mathrm{C} 204-\mathrm{C} 209$ & $125.4(3)$ \\
\hline $\mathrm{C} 203-\mathrm{C} 204-\mathrm{C} 209$ & $126.3(3)$ \\
\hline $\mathrm{C} 204-\mathrm{C} 205-\mathrm{C} 201$ & $107.8(3)$ \\
\hline $\mathrm{C} 204-\mathrm{C} 205-\mathrm{C} 210$ & $126.0(3)$ \\
\hline $\mathrm{C} 201-\mathrm{C} 205-\mathrm{C} 210$ & $126.2(3)$ \\
\hline $\mathrm{N} 201-\mathrm{C} 206-\mathrm{C} 201$ & $177.0(4)$ \\
\hline $\mathrm{N} 202-\mathrm{C} 207-\mathrm{C} 202$ & $179.2(4)$ \\
\hline $\mathrm{N} 203-\mathrm{C} 208-\mathrm{C} 203$ & $178.8(4)$ \\
\hline $\mathrm{N} 204-\mathrm{C} 209-\mathrm{C} 204$ & $179.3(4)$ \\
\hline $\mathrm{C} 105-\mathrm{C} 101-\mathrm{C} 102-\mathrm{C} 103$ & $0.0(4)$ \\
\hline $\mathrm{C} 106-\mathrm{C} 101-\mathrm{C} 102-\mathrm{C} 103$ & $179.8(3)$ \\
\hline $\mathrm{C} 105-\mathrm{C} 101-\mathrm{C} 102-\mathrm{C} 107$ & $-179.5(3)$ \\
\hline $\mathrm{C} 106-\mathrm{C} 101-\mathrm{C} 102-\mathrm{C} 107$ & $0.3(6)$ \\
\hline $\mathrm{C} 101-\mathrm{C} 102-\mathrm{C} 103-\mathrm{C} 104$ & $-0.2(4)$ \\
\hline $\mathrm{C} 107-\mathrm{C} 102-\mathrm{C} 103-\mathrm{C} 104$ & $179.4(3)$ \\
\hline $\mathrm{C} 101-\mathrm{C} 102-\mathrm{C} 103-\mathrm{C} 108$ & $179.3(3)$ \\
\hline $\mathrm{C} 107-\mathrm{C} 102-\mathrm{C} 103-\mathrm{C} 108$ & $-1.1(6)$ \\
\hline $\mathrm{C} 102-\mathrm{C} 103-\mathrm{C} 104-\mathrm{C} 105$ & $0.2(4)$ \\
\hline
\end{tabular}

\begin{tabular}{|c|c|}
\hline $\mathrm{C} 21-\mathrm{N} 2-\mathrm{Fe} 1$ & $178.6(3)$ \\
\hline $\mathrm{N} 3-\mathrm{C} 31-\mathrm{C} 32$ & $178.2(6)$ \\
\hline $\mathrm{C} 31-\mathrm{C} 32-\mathrm{H} 32 \mathrm{~A}$ & 109.5 \\
\hline $\mathrm{C} 31-\mathrm{C} 32-\mathrm{H} 32 \mathrm{~B}$ & 109.5 \\
\hline $\mathrm{H} 32 \mathrm{~A}-\mathrm{C} 32-\mathrm{H} 32 \mathrm{~B}$ & 109.5 \\
\hline $\mathrm{C} 31-\mathrm{C} 32-\mathrm{H} 32 \mathrm{C}$ & 109.5 \\
\hline $\mathrm{H} 32 \mathrm{~A}-\mathrm{C} 32-\mathrm{H} 32 \mathrm{C}$ & 109.5 \\
\hline $\mathrm{H} 32 \mathrm{~B}-\mathrm{C} 32-\mathrm{H} 32 \mathrm{C}$ & 109.5 \\
\hline $\mathrm{C} 31-\mathrm{N} 3-\mathrm{Fe} 1$ & $166.2(4)$ \\
\hline $\mathrm{N} 4-\mathrm{C} 41-\mathrm{C} 42$ & $179.0(5)$ \\
\hline $\mathrm{C} 41-\mathrm{C} 42-\mathrm{H} 42 \mathrm{~A}$ & 109.5 \\
\hline $\mathrm{C} 41-\mathrm{C} 42-\mathrm{H} 42 \mathrm{~B}$ & 109.5 \\
\hline $\mathrm{H} 42 \mathrm{~A}-\mathrm{C} 42-\mathrm{H} 42 \mathrm{~B}$ & 109.5 \\
\hline $\mathrm{C} 41-\mathrm{C} 42-\mathrm{H} 42 \mathrm{C}$ & 109.5 \\
\hline $\mathrm{H} 42 \mathrm{~A}-\mathrm{C} 42-\mathrm{H} 42 \mathrm{C}$ & 109.5 \\
\hline $\mathrm{H} 42 \mathrm{~B}-\mathrm{C} 42-\mathrm{H} 42 \mathrm{C}$ & 109.5 \\
\hline $\mathrm{C} 41-\mathrm{N} 4-\mathrm{Fe} 1$ & $165.3(3)$ \\
\hline $\mathrm{N} 5 \mathrm{~A}-\mathrm{C} 51 \mathrm{~A}-\mathrm{C} 52 \mathrm{~A}$ & $177.7(8)$ \\
\hline $\mathrm{C} 51 \mathrm{~A}-\mathrm{C} 52 \mathrm{~A}-\mathrm{H} 52 \mathrm{~A}$ & 109.5 \\
\hline $\mathrm{C} 51 \mathrm{~A}-\mathrm{C} 52 \mathrm{~A}-\mathrm{H} 52 \mathrm{~B}$ & 109.5 \\
\hline $\mathrm{H} 52 \mathrm{~A}-\mathrm{C} 52 \mathrm{~A}-\mathrm{H} 52 \mathrm{~B}$ & 109.5 \\
\hline $\mathrm{C} 51 \mathrm{~A}-\mathrm{C} 52 \mathrm{~A}-\mathrm{H} 52 \mathrm{C}$ & 109.5 \\
\hline $\mathrm{H} 52 \mathrm{~A}-\mathrm{C} 52 \mathrm{~A}-\mathrm{H} 52 \mathrm{C}$ & 109.5 \\
\hline $\mathrm{H} 52 \mathrm{~B}-\mathrm{C} 52 \mathrm{~A}-\mathrm{H} 52 \mathrm{C}$ & 109.5 \\
\hline $\mathrm{N} 6 \mathrm{~A}-\mathrm{C} 61 \mathrm{~A}-\mathrm{C} 62 \mathrm{~A}$ & $178.7(9)$ \\
\hline $\mathrm{C} 61 \mathrm{~A}-\mathrm{C} 62 \mathrm{~A}-\mathrm{H} 62 \mathrm{~A}$ & 109.5 \\
\hline $\mathrm{C} 61 \mathrm{~A}-\mathrm{C} 62 \mathrm{~A}-\mathrm{H} 62 \mathrm{~B}$ & 109.5 \\
\hline $\mathrm{H} 62 \mathrm{~A}-\mathrm{C} 62 \mathrm{~A}-\mathrm{H} 62 \mathrm{~B}$ & 109.5 \\
\hline $\mathrm{C} 61 \mathrm{~A}-\mathrm{C} 62 \mathrm{~A}-\mathrm{H} 62 \mathrm{C}$ & 109.5 \\
\hline $\mathrm{H} 62 \mathrm{~A}-\mathrm{C} 62 \mathrm{~A}-\mathrm{H} 62 \mathrm{C}$ & 109.5 \\
\hline $\mathrm{H} 62 \mathrm{~B}-\mathrm{C} 62 \mathrm{~A}-\mathrm{H} 62 \mathrm{C}$ & 109.5 \\
\hline $\mathrm{N} 6 \mathrm{~B}-\mathrm{C} 61 \mathrm{~B}-\mathrm{C} 62 \mathrm{~B}$ & $173(6)$ \\
\hline $\mathrm{C} 61 \mathrm{~B}-\mathrm{C} 62 \mathrm{~B}-\mathrm{H} 62 \mathrm{D}$ & 109.5 \\
\hline $\mathrm{C} 61 \mathrm{~B}-\mathrm{C} 62 \mathrm{~B}-\mathrm{H} 62 \mathrm{E}$ & 109.5 \\
\hline $\mathrm{H} 62 \mathrm{D}-\mathrm{C} 62 \mathrm{~B}-\mathrm{H} 62 \mathrm{E}$ & 109.5 \\
\hline $\mathrm{C} 61 \mathrm{~B}-\mathrm{C} 62 \mathrm{~B}-\mathrm{H} 62 \mathrm{~F}$ & 109.5 \\
\hline $\mathrm{H} 62 \mathrm{D}-\mathrm{C} 62 \mathrm{~B}-\mathrm{H} 62 \mathrm{~F}$ & 109.5 \\
\hline $\mathrm{H} 62 \mathrm{E}-\mathrm{C} 62 \mathrm{~B}-\mathrm{H} 62 \mathrm{~F}$ & 109.5 \\
\hline $\mathrm{C} 205-\mathrm{C} 201-\mathrm{C} 202-\mathrm{C} 203$ & $0.2(4)$ \\
\hline $\mathrm{C} 206-\mathrm{C} 201-\mathrm{C} 202-\mathrm{C} 203$ & $179.5(3)$ \\
\hline $\mathrm{C} 205-\mathrm{C} 201-\mathrm{C} 202-\mathrm{C} 207$ & $179.8(3)$ \\
\hline $\mathrm{C} 206-\mathrm{C} 201-\mathrm{C} 202-\mathrm{C} 207$ & $-0.9(6)$ \\
\hline $\mathrm{C} 201-\mathrm{C} 202-\mathrm{C} 203-\mathrm{C} 204$ & $0.0(4)$ \\
\hline $\mathrm{C} 207-\mathrm{C} 202-\mathrm{C} 203-\mathrm{C} 204$ & $-179.7(3)$ \\
\hline $\mathrm{C} 201-\mathrm{C} 202-\mathrm{C} 203-\mathrm{C} 208$ & $-179.2(3)$ \\
\hline $\mathrm{C} 207-\mathrm{C} 202-\mathrm{C} 203-\mathrm{C} 208$ & $1.2(6)$ \\
\hline $\mathrm{C} 202-\mathrm{C} 203-\mathrm{C} 204-\mathrm{C} 205$ & $-0.2(4)$ \\
\hline
\end{tabular}




$\begin{array}{ll}\mathrm{C} 108-\mathrm{C} 103-\mathrm{C} 104-\mathrm{C} 105 & -179.3(3) \\ \mathrm{C} 102-\mathrm{C} 103-\mathrm{C} 104-\mathrm{C} 109 & -179.1(3) \\ \mathrm{C} 108-\mathrm{C} 103-\mathrm{C} 104-\mathrm{C} 109 & 1.4(6) \\ \mathrm{C} 103-\mathrm{C} 104-\mathrm{C} 105-\mathrm{C} 101 & -0.2(4) \\ \mathrm{C} 109-\mathrm{C} 104-\mathrm{C} 105-\mathrm{C} 101 & 179.1(3) \\ \mathrm{C} 103-\mathrm{C} 104-\mathrm{C} 105-\mathrm{C} 110 & 179.9(3) \\ \mathrm{C} 109-\mathrm{C} 104-\mathrm{C} 105-\mathrm{C} 110 & -0.8(6) \\ \mathrm{C} 102-\mathrm{C} 101-\mathrm{C} 105-\mathrm{C} 104 & 0.1(4) \\ \mathrm{C} 106-\mathrm{C} 101-\mathrm{C} 105-\mathrm{C} 104 & -179.7(3) \\ \mathrm{C} 102-\mathrm{C} 101-\mathrm{C} 105-\mathrm{C} 110 & -180.0(3) \\ \mathrm{C} 106-\mathrm{C} 101-\mathrm{C} 105-\mathrm{C} 110 & 0.2(6)\end{array}$

$\begin{array}{ll}\mathrm{C} 208-\mathrm{C} 203-\mathrm{C} 204-\mathrm{C} 205 & 179.1(3) \\ \mathrm{C} 202-\mathrm{C} 203-\mathrm{C} 204-\mathrm{C} 209 & 179.6(3) \\ \mathrm{C} 208-\mathrm{C} 203-\mathrm{C} 204-\mathrm{C} 209 & -1.2(6) \\ \mathrm{C} 203-\mathrm{C} 204-\mathrm{C} 205-\mathrm{C} 201 & 0.3(4) \\ \mathrm{C} 209-\mathrm{C} 204-\mathrm{C} 205-\mathrm{C} 201 & -179.5(3) \\ \mathrm{C} 203-\mathrm{C} 204-\mathrm{C} 205-\mathrm{C} 210 & -179.4(3) \\ \mathrm{C} 209-\mathrm{C} 204-\mathrm{C} 205-\mathrm{C} 210 & 0.8(6) \\ \mathrm{C} 202-\mathrm{C} 201-\mathrm{C} 205-\mathrm{C} 204 & -0.3(4) \\ \mathrm{C} 206-\mathrm{C} 201-\mathrm{C} 205-\mathrm{C} 204 & -179.6(3) \\ \mathrm{C} 202-\mathrm{C} 201-\mathrm{C} 205-\mathrm{C} 210 & 179.4(3) \\ \mathrm{C} 206-\mathrm{C} 201-\mathrm{C} 205-\mathrm{C} 210 & 0.1(6)\end{array}$

Hydrogen-bond geometry $\left(A,{ }^{\circ}\right)$

\begin{tabular}{lllll}
\hline$D-\mathrm{H} \cdots A$ & $D-\mathrm{H}$ & $\mathrm{H} \cdots A$ & $D \cdots A$ & $D-\mathrm{H} \cdots A$ \\
\hline $\mathrm{C} 12-\mathrm{H} 12 A \cdots \mathrm{N} 5 A^{\mathrm{i}}$ & 0.98 & 2.58 & $3.454(7)$ & 149 \\
$\mathrm{C} 12-\mathrm{H} 12 B \cdots \mathrm{N} 103^{\mathrm{i}}$ & 0.98 & 2.54 & $3.443(6)$ & 154 \\
$\mathrm{C} 12-\mathrm{H} 12 C \cdots \mathrm{N} 204^{\text {ii }}$ & 0.98 & 2.56 & $3.469(6)$ & 154 \\
$\mathrm{C} 22-\mathrm{H} 22 A \cdots \mathrm{N} 5 A^{\mathrm{iii}}$ & 0.98 & 2.39 & $3.308(7)$ & 156 \\
$\mathrm{C} 22-\mathrm{H} 22 A \cdots \mathrm{N} 6 B^{\text {iv }}$ & 0.98 & 2.61 & $3.41(3)$ & 138 \\
$\mathrm{C} 22-\mathrm{H} 22 B \cdots \mathrm{N} 204^{\mathrm{v}}$ & 0.98 & 2.52 & $3.407(5)$ & 150 \\
$\mathrm{C} 22-\mathrm{H} 22 C \cdots \mathrm{N} 103^{\mathrm{iii}}$ & 0.98 & 2.52 & $3.424(6)$ & 154 \\
$\mathrm{C} 52-\mathrm{H} 52 B \cdots \mathrm{N} 102$ & 0.98 & 2.51 & $3.492(8)$ & 176
\end{tabular}

Symmetry codes: (i) $x, y, z+1$; (ii) $x, y-1, z$; (iii) $x, y+1, z$; (iv) $-x+1,-y+1,-z+1$; (v) $x, y, z^{-1}$.

The geometry $\left(A{ }^{\circ}\right)$ around the $F e^{I I}$ ion

\begin{tabular}{llll}
\hline $\mathrm{Fe} 1-\mathrm{N} 101$ & $2.170(4)$ & $\mathrm{N} 101-\mathrm{Fe} 1-\mathrm{N} 201$ & $98.6(1)$ \\
$\mathrm{Fe} 1-\mathrm{N} 201$ & $2.186(3)$ & $\mathrm{N} 101-\mathrm{Fe} 1-\mathrm{N} 3$ & $174.6(1)$ \\
$\mathrm{Fe} 1-\mathrm{N} 1$ & $2.127(3)$ & $\mathrm{N} 201-\mathrm{Fe} 1-\mathrm{N} 4$ & $173.0(1)$ \\
$\mathrm{Fe} 1-\mathrm{N} 2$ & $2.141(3)$ & $\mathrm{N} 1-\mathrm{Fe} 1-\mathrm{N} 2$ & $175.8(1)$ \\
$\mathrm{Fe} 1-\mathrm{N} 3$ & $2.143(4)$ & $\mathrm{C} 206-\mathrm{N} 101-\mathrm{Fe} 1$ & $162.5(3)$ \\
$\mathrm{Fe} 1-\mathrm{N} 4$ & $2.146(3)$ & $\mathrm{Fe} 1$ & $161.2(3)$ \\
\hline
\end{tabular}

Hydrogen-bond geometry $\left(\AA,{ }^{\circ}\right)$

\begin{tabular}{lllll}
\hline$D-\mathrm{H}^{\cdots} \cdots A$ & $\mathrm{H}-\mathrm{H} \cdots A$ & $D \cdots A$ & $D-\mathrm{H} \cdots A$ \\
$\mathrm{C} 12-\mathrm{H} 12 A \cdots \mathrm{N} 5^{\mathrm{i}}$ & 0.98 & 2.57 & 3.448 & 149 \\
$\mathrm{C} 12-\mathrm{H} 12 B \cdots \mathrm{N} 103^{\mathrm{i}}$ & 0.98 & 2.54 & $3.440(5)$ & 154 \\
$\mathrm{C} 12-\mathrm{H} 12 C \cdots \mathrm{N} 204^{\mathrm{ii}}$ & 0.98 & 2.57 & $3.469(5)$ & 153 \\
$\mathrm{C} 22-\mathrm{H} 22 A \cdots \mathrm{N} 5^{\text {iv }}$ & 0.98 & 2.38 & 3.302 & 156 \\
$\mathrm{C} 22-\mathrm{H} 22 A \cdots \mathrm{N} 6 \mathrm{~B}^{\mathrm{v}}$ & 0.98 & 2.64 & 3.426 & 137 \\
$\mathrm{C} 22-\mathrm{H} 22 B \cdots \mathrm{N} 204^{\text {iii }}$ & 0.98 & 2.53 & $3.406(5)$ & 149 \\
$\mathrm{C} 22-\mathrm{H} 22 C \cdots \cdots \mathrm{N} 103^{3 \text { iv }}$ & 0.98 & 2.52 & $3.421(5)$ & 153 \\
$\mathrm{C} 52-\mathrm{H} 52 B \cdots \mathrm{N} 102$ & 0.98 & 2.51 & 3.489 & 177 \\
\hline
\end{tabular}

Symmetry codes: (i) $\mathrm{x}, \mathrm{y}, \mathrm{z}+1$; (ii) $\mathrm{x}, \mathrm{y}-1, \mathrm{z}$; (iii) $\mathrm{x}, \mathrm{y}, \mathrm{z}-1$; (iv) $\mathrm{x}, \mathrm{y}+1, \mathrm{z}$; (v) $-\mathrm{x}+1,-\mathrm{y}+1,-\mathrm{z}+1$. 